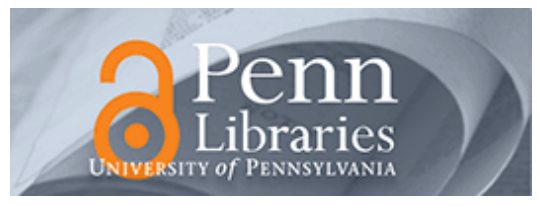

University of Pennsylvania

ScholarlyCommons

Finance Papers

Wharton Faculty Research

2011

\title{
An Empirical Model of Optimal Capital Structure
}

Jules van Binsbergen

University of Pennsylvania

John R. Graham

Jie Yang

Follow this and additional works at: https://repository.upenn.edu/fnce_papers

Part of the Corporate Finance Commons, Finance Commons, and the Finance and Financial Management Commons

\section{Recommended Citation}

van Binsbergen, J., Graham, J. R., \& Yang, J. (2011). An Empirical Model of Optimal Capital Structure. Journal of Applied Corporate Finance, 23 (4), 34-59. http://dx.doi.org/10.1111/j.1745-6622.2011.00351.x

This paper is posted at ScholarlyCommons. https://repository.upenn.edu/fnce_papers/265

For more information, please contact repository@pobox.upenn.edu. 


\title{
An Empirical Model of Optimal Capital Structure
}

\begin{abstract}
The authors provide a reasonably user-friendly and intuitive model for arriving at a company's optimal, or value-maximizing, leverage ratio that is based on the estimation of company-specific cost and benefit functions for debt financing. The benefit functions are downward-sloping, reflecting the drop in the incremental value of debt with increases in the amount used. The cost functions are upward-sloping, reflecting the increase in costs associated with increases in leverage. The cost functions vary among companies in ways that reflect differences in corporate characteristics such as size, profitability, dividend policy, book-to-market ratio, and asset collateral and redeployability.

The authors use these cost and benefit functions to produce an estimate of a company's optimal amount of debt. Just as equilibrium in economics textbooks occurs where supply equals demand, optimal capital structure occurs at the point where the marginal benefit of debt equals the marginal cost. The article illustrates optimal debt choices for companies such as Barnes \& Noble, Coca-Cola, Six Flags, and Performance Food Group. The authors also estimate the net benefit of debt usage (in terms of the increase in firm or enterprise value) for companies that are optimally levered, as well as the net cost of being underleveraged for companies with too little debt, and the cost of overleveraging for companies with too much. One critical insight of the model is that the costs associated with overleveraging appear to be significantly higher, at least for some companies, than the costs of being underleveraged.

Disciplines

Corporate Finance | Finance | Finance and Financial Management
\end{abstract}




\title{
Optimal Capital Structure*
}

\author{
Jules H. van Binsbergen, John R. Graham, and Jie Yang
}

This version: April 2011

\begin{abstract}
We study optimal capital structure by first estimating firm-specific cost and benefit functions for debt. The benefit functions are downward sloping reflecting that the incremental value of debt declines as more debt is used. The cost functions are upward sloping, reflecting the rising costs that occur as a firm increases its use of debt. The cost functions vary by firm to reflect the firm's characteristics such as asset collateral and redeployability, asset size, the book-to-market ratio, profitability, and whether the firm pays dividends.

We use these cost and benefit functions to produce a firm-specific recommendation of the optimal amount of debt that a given company should use. In textbook economics, equilibrium occurs where supply equals demand. Analogously, optimal capital structure occurs where the marginal benefit equals the marginal cost of debt. We illustrate optimal debt choices for specific firms such as Barnes \& Noble, Coca-Cola, Six Flags, and Performance Food Group, among others. We also calculate the cost of being underlevered for companies that use too little debt, the cost of being overlevered for companies that use too much debt, and the net benefit of debt usage for those that are correctly levered. Finally, we provide formulas that can be easily used to approximate the cost of debt function, and in turn to determine the optimal amount of debt, for any given firm.
\end{abstract}

\footnotetext{
*van Binsbergen is from the Kellogg Graduate School of Management, Northwestern University, and the Graduate School of Business, Stanford University, and NBER; Graham is from the Fuqua School of Business, Duke University, and NBER; and Yang is from the McDonough School of Business, Georgetown University. This paper updates our paper "The Cost of Debt" published in the Journal of Finance (December 2010), with a particular focus on a practitioner audience.
} 


\section{Introduction}

How much debt should a company use, and how does the use of debt affect firm value? Hundreds of research papers investigate corporate capital structure in an attempt to answer these questions. Theoretical papers agree that there are many benefits to using debt, including the tax benefits of interest deductibility, oversight and monitoring by intermediaries and financial markets, and the reduction in agency costs that might result from too plentiful free cash flows. The costs of debt include financial distress and bankruptcy costs, the possibility that a firm will pass up positive net present value projects if it has too much debt overhang, and the agency costs that can result if debt creates conflicts between managerial objectives versus those of bondholders and stockholders.

Despite all this research, a consensus view on optimal capital structure has yet to emerge. Consequently, in many cases it is difficult to make a specific recommendation about how much debt a given company should use. In this paper, we develop an approach that allows us to make specific recommendations about the optimal amount of debt that any given firm should use 1 We do this by estimating cost and benefit of debt functions for thousands of companies that appear to make unconstrained, optimal capital structure choices. In essence, we observe the choices made by firms that appear to behave optimally, which we use to statistically deduce optimal capital structure recommendations for firms with similar characteristics (similar profitability, asset size, collateral, etc).

Our approach starts with the estimation of firm-specific debt benefit functions. Because tax benefits are relatively easy to quantify, we focus the debt benefit functions on the present value of expected tax savings associated with interest deductions. Using the tax benefits of debt as a reference point, we can implicitly back out the associated cost of debt and map these costs to observable firm characteristics. Note that although we start by estimating tax benefits, our approach captures any and all benefits and costs of debt that influence debt choices, such as the benefits of committing to pay out free cash flows and the cost of financial distress, among other influences. More specifically, our approach involves estimating cost of debt functions for a subset of firms that appear to make unconstrained, optimal debt choices. These functions capture the cost associated with any given amount of debt and allow debt costs to vary conditional on a given firm's profitability, collateral, firm size, investment opportunities, asset tangibility, and dividend policy. Based on these functions, we are able to deduce what the cost of debt would be for any firm with a given set of characteristics.

It is worthwhile to emphasize that our cost estimates capture all possible costs associated

\footnotetext{
${ }^{1}$ In this paper, we focus on the total amount of debt financing that a firm should optimally use, but do not address whether the debt should be short-term or long-term, variable or fixed, etc.
} 
Alltel, 2006

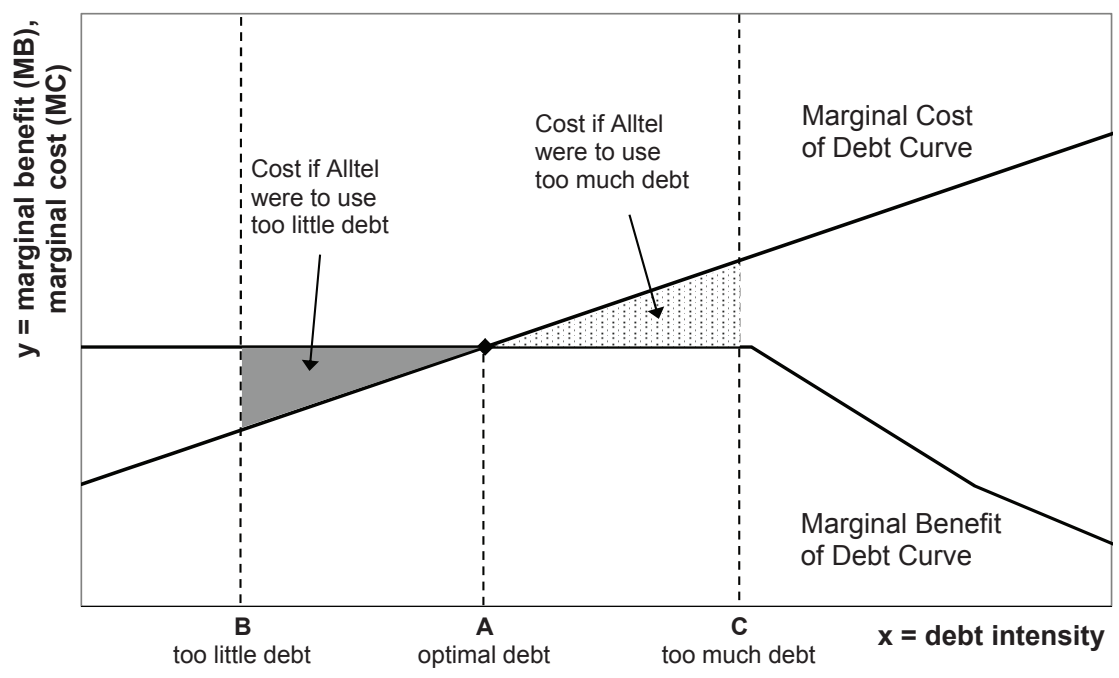

Figure 1: Marginal benefit and marginal cost curves of debt for Alltel in 2006. The intersection of the two curves reflect the optimal amount of debt (point A). Having debt below the optimal amount results in too little debt (point B) and having debt above the optimal results in too much debt (point C). The shaded and dotted areas reflect the cost to underlevering and overlevering, respectively.

with using debt (i.e., not just distress costs). Moreover, as explained in more detail below, any benefit not captured by our measure of debt benefits is also captured in our cost of debt functions (and will enter these functions as "negative costs"). For example, the disciplining benefit of debt that causes cash-rich firms to commit to paying out free cash flows and "run a tight ship" is captured in our costs functions. By comparing our "all-in" estimate of the cost of debt to explicit measures of default costs, we can estimate the magnitude of non-default costs of debt. Our estimate imply that agency and other non-default costs are approximately the same magnitude as default costs.

Given these firm-specific estimates of cost and benefit of debt functions, we can estimate firm-specific optimal capital structures. In undergraduate economics we learn that market equilibrium occurs where demand equals supply (i.e., where the demand curve intersects the supply curve). Analogously, in our setting, the optimal capital structure occurs where the marginal benefit of debt function intersects the marginal cost of debt function. Thus, for any given firm, we can determine its optimal debt choice as the debt ratio located at the intersection of the firm's marginal cost and marginal benefit of debt curves.

For example, consider the marginal benefit and marginal cost functions to Alltel in 2006 (shown in Figure 1). The optimal amount of debt for Alltel in 2006 occurs at the intersection of the marginal benefit and marginal cost curves (at point A in Figure 1). If Alltel were to use too little debt (e.g., at point B), the benefit of using more debt would be greater than the 
cost of using more, so the company could increase firm value by using more debt. If a firm uses too much debt (e.g., at point C), the benefit of the last dollars of debt are less valuable than the costs, so the company could increase firm value by reducing its debt usage to point A. We are able to explicitly quantify the dollar cost of being underlevered (the shaded area in Figure 1 if Alltel were to use B amount of debt), as well as the cost of being overlevered (the dotted area if Alltel were to use $\mathrm{C}$ amount of debt). We also calculate the net benefit of debt, that is, the amount of firm value contributed by the optimal use of debt. We find that for the average firm, the net benefit of debt (i.e., benefits net of costs) equals about $3 \%$ of market value, while the gross benefits of debt (i.e., benefits ignoring costs) are about $8 \%$ of firm value. For some companies, the benefits are much greater.

Being able to make specific, firm-by-firm debt policy recommendations is an important addition to the current state of affairs. Though much progress has been made in capital structure research, empirical academic research tends to use reduced form regressions to identify the factors that are correlated with debt ratios. While this approach can make directional predictions related to corporate characteristics (e.g., firms with collateral use more debt on average), it does not explicitly separate out the benefits and costs of debt to facilitate predictions about optimal debt ratios, nor can the reduced form approach precisely quantify the cost of suboptimal leverage. Theoretical capital structure research can be used to derive an optimal debt ratio and to provide qualitative predications about capital structure. However, in order to keep the model tractable, most models focus on one or two costs or benefits of debt.

In our approach, we use actual capital structure choices to implicitly back out the cost of debt, and this estimated cost of debt encompasses all the ex ante costs that affect corporate financing choices. All else equal, companies that do not use much debt often face large costs, which translates into a "high" cost of debt curve in our approach. Reassuringly, the costs implied in our analysis are consistent in sign with the costs estimated in other empirical research. With the estimated cost and benefit functions we can determine directional (sign) effects, for example, whether firms with collateral face lower costs of debt (and therefore use more debt). Moreover, with our cost-benefit framework, we can make explicit recommendations about optimal capital structure, estimate the value added by using the model-recommended amount of debt, and address other issues that are described below. 


\section{Estimating Cost and Benefit Functions for Debt}

To determine optimal capital structure for a given firm, our approach requires that we first estimate marginal benefit functions of debt and marginal cost functions of debt. The optimal capital structure occurs at the intersection of these benefit and cost curves. Thinking in terms of Figure 1, these curves relate marginal benefit and marginal cost (on the y-axis) to a measure of debt intensity (on the x-axis). As explained in more detail later, we use interest expense divided by the book value of assets as our measure of debt intensity (on the x-axis), though our results hold if we were to instead use debt over assets or debt over market value of the firm as our debt measure. In the next section, we explain how we simulate tax benefit curves for debt. As described in Section 2.2, we use variation in those benefit curves to identify debt cost curves. Section 2.3 provides an easy to use formula to calculate firm-specific cost of debt functions.

\subsection{The Tax Benefit of Debt}

We simulate tax benefit functions using the methodology of Graham (2001). Consider the value of an additional dollar of interest deduction for the hypothetical firm depicted in Figure 2. The company currently uses $\$ 4$ of interest, as reflected as the point where $x^{*}=4$ on the horizontal axis. At this level of interest, the company's marginal tax rate is currently 0.25 , and therefore, an extra dollar of interest deduction is expected to save the company $\$ 0.25$ in taxes this year. That is, the marginal tax benefit of the fourth dollar of interest is $\$ 0.25$.

It's worth taking a minute to explain how a company's marginal tax rate could be 0.25. Assume that the top corporate marginal tax rate is 0.35 . In the simplest setting, a company could have a $5 / 7$ probability of being profitable (and taxed), and a 2/7 chance of being unprofitable (and not taxed), and therefore have an expected marginal tax rate of 0.25 ( = $\left.0.35^{*}(5 / 7)+0 *(2 / 7)\right)$. Our approach captures the probability that a firm will be profitable, like in this example, but is much more sophisticated. As outlined in the footnote, we also model the tax-loss carryback and carryforward features of the tax code. 2 as well as investment

\footnotetext{
${ }^{2}$ Consider how the tax-loss carryforward feature can affect expected marginal tax rates. Assume that a firm is losing $\$ 10$ today but expects to earn $\$ 20$ next year. This company would carry forward the $\$ 10$ loss and only pay taxes on $\$ 10$ next year. This would lead to $\$ 3.50$ in taxes next year if the corporate marginal income tax rate is $35 \%$. If this firm were to earn an extra dollar of income today, it would lose $\$ 9$ rather than $\$ 10$, and only carry forward a $\$ 9$ loss. Given a $\$ 1$ smaller loss to carry forward, next year the company would pay tax of $\$ 3.85$ on $\$ 11$ of taxable income. Therefore, the present value of taxes owed on an extra dollar of income earned today (that is, the expected marginal tax rate) is $0.32 \approx 0.35 / 1.10$ if the discount rate is $10 \%$. More generally, in our algorithm to determine corporate marginal tax rates we consider the full-blown carryforward and carryback features of the tax code. For example, in 2010 the tax loss carryback period is two years and the carryforward period 20 years (though the carryback was temporarily extended
} 


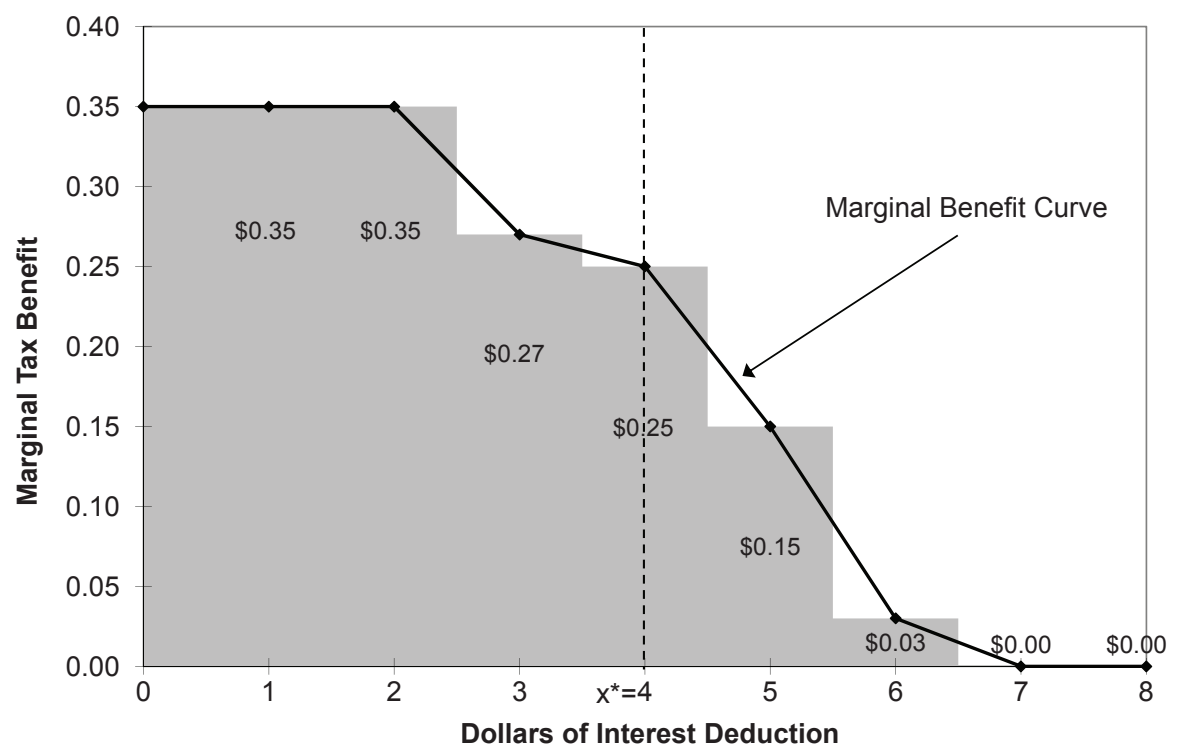

Figure 2: The figure depicts the marginal tax benefit of debt curve for a hypothetical firm. Each rectangular box represents the present value tax benefit of adding another dollar of interest deduction. By adding up the area inside all of the rectangular boxes, we integrate under the benefit function to determine the area under the curve, $A R E A_{i, t}$. Notice how the marginal benefit of debt is a downward sloping, declining function of the level of interest deductions, reflecting the declining value of each incremental dollar of interest deduction. $x^{*}$ depicts the observed interest deduction level for our hypothetical firm.

tax credits and the alternative minimum tax. Considering these dynamic features of the tax code requires forecasting future taxable income, in order to determine the present value of taxes owed if the firm were to earn an extra dollar of income this year. The bottom line is that we can estimate expected marginal tax rates for any given firm at any given level of income in any year. Knowing the marginal tax rate allows us to determine the tax benefit of debt because one additional dollar of interest deduction would save the company an amount of taxes equal to its marginal tax rate in the year the deduction is relevant. Therefore, the marginal tax benefit of an incremental dollar of interest equals the present value of the marginal tax rate for a given level of taxable income.

Let's return to the example shown in Figure 2 and evaluate the marginal tax benefit that the company would realize if it deducted $\$ 5$ in interest. The figure shows that the marginal benefit of the 5th dollar of interest is $\$ 0.15$. This implies that the marginal tax rate of the company is only $15 \%$ when the company has $\$ 5$ of interest deductions. To see how this could be the case, note that interest deductions reduce taxable income, and therefore, using more debt reduces a company's expected marginal tax rate. In this example, extra deductions

to five years in 2008 and 2009). We forecast taxable income using a random walk with drift model (see Graham (2000)) in order to determine the present value effects of income earned today in companies that might experience losses today or in the future. 
would reduce the marginal tax rate because the incremental interest deductions push down taxable income so much that there is now a $4 / 7$ chance that the firm will be unprofitable, so its marginal tax rate is $0.15(=0.35 *(3 / 7)+0 *(4 / 7))$.

At the other end of the spectrum, what would the company's marginal tax rate be if it did not have any interest deductions? In this case, the company's marginal tax rate is $35 \%$. This implies that the company is fully taxable in all possible scenarios, or has a loss small enough that it is fully utilized by tax loss carrybacks, so there is a $7 / 7$ chance that the firm will pay taxes of $\$ 0.35$ on an extra dollar of income earned today. This also means that if the company used debt, the first dollar of interest would save the firm $\$ 0.35$ in taxes, and increase its cash flow by the same amount.

The marginal tax benefit function in Figure 2 maps out the tax benefit of each dollar of interest deduction. Note that the benefit function is initially flat at 0.35 (representing the "fully taxable outcomes" that occur when the company has few interest deductions), then becomes downward sloping at $\$ 2$ of interest at the "kink" in the benefit function. At $\$ 7$ of interest, the marginal benefit of an extra dollar of interest is zero. This occurs because if the company had $\$ 7$ of interest deductions this year, it would produce a taxable loss so large that the company would not pay taxes in any year during the entire tax-loss carryback or carryforward forecast horizon. (Under current law, losses can be carried back two years to shield income in t-2 and t-1, or can be carried forward 20 years to shield profits in any year up to $\mathrm{t}+20)$.

The total tax benefit of the firm's chosen amount of interest deductions is represented by the area under the benefit function up to $x^{*}$. In the Figure 2 example, $\$ 4$ of interest saves the firm $\$ 1.22$ in taxes $(\$ 0.35+\$ 0.35+\$ 0.27+\$ 0.25)$, and increases cash flow by a like amount, in the current year. Note that this gross tax benefit calculation ignores all costs of debt. We now turn our attention to estimating the costs of debt.

\subsection{The Cost of Debt}

Consider the three points depicted in Figure 3A. Assume that these points represent the actual amount of interest used by three different companies making optimal debt choices in 2010 (shown as $x_{1}^{*}, x_{2}^{*}$, and $x_{3}^{*}$ ). In order to map out the marginal cost function (or in the language of statistics, to identify the cost curve), we need all of the variation in debt usage to occur because of benefit function shifts while the cost function remains fixed in one place. In this ideal setting, we can then "connect the dots" and trace out the marginal cost curve of debt, as depicted in Figure 3 B. In general, however, when you observe real world debt choices by three different firms, you can not tell whether these choices are due to shifts in the 

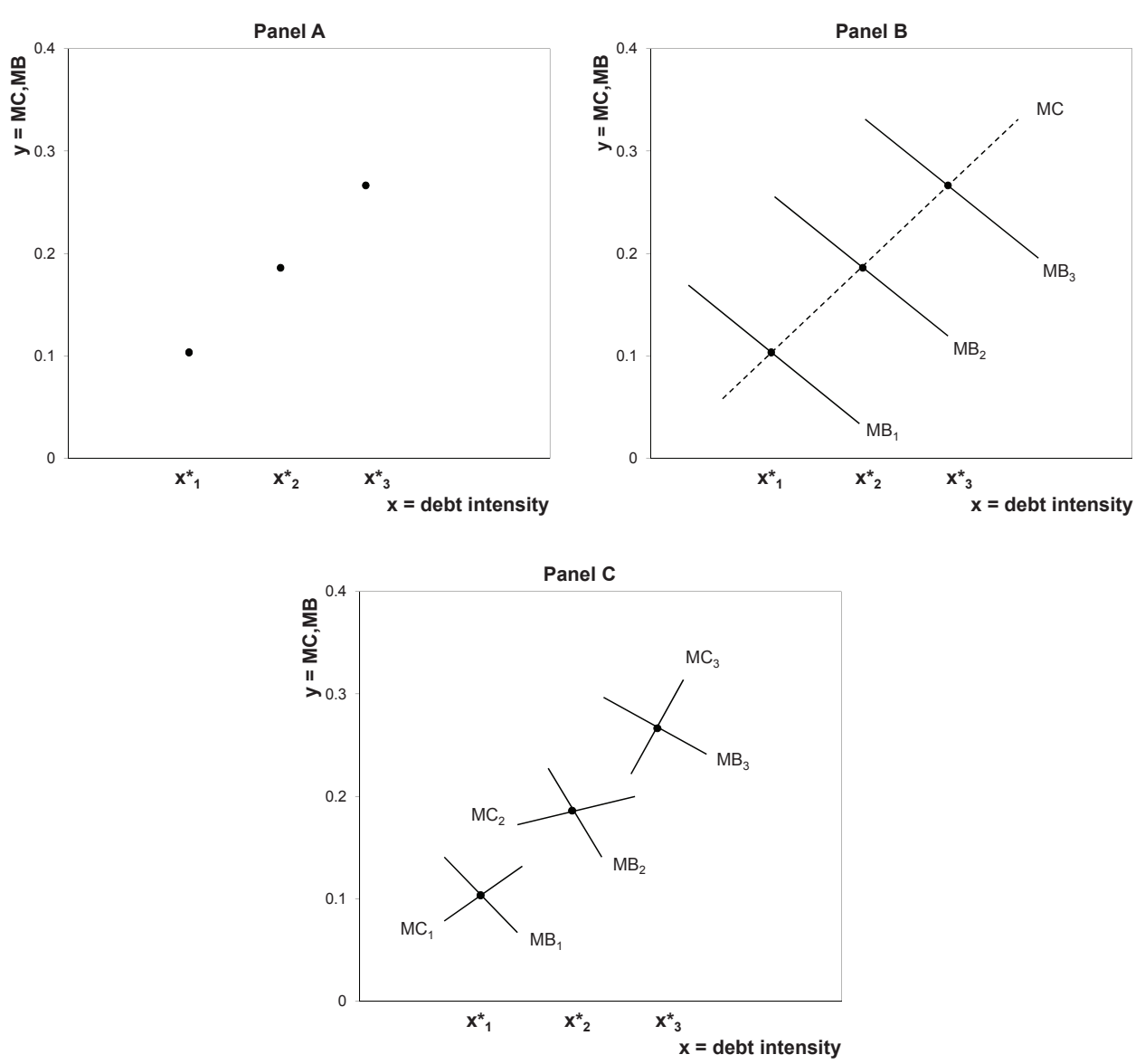

Figure 3: A) Optimal capital structure choices of three different companies: 1, 2, and 3. B) The ideal setting when all movements between points are due to benefit curve shifts and the cost curve stays the same. The shift in the benefit function is depicted by showing three different marginal benefit functions, $\mathrm{MB}_{1}, \mathrm{MB}_{2}$, and $\mathrm{MB}_{3}$. This allows us to "connect the dots" to identify the marginal cost curve. C) The general setting when movements between points are due to a combination of shifts in both the marginal benefit function and the marginal cost function. It is not possible to identify the cost curve in this setting.

benefit function while the cost function remains fixed (the ideal setting), shifts in the cost function while the benefit function remains fixed, or a combination of shifts in both curves where neither curve remains fixed (as shown in Figure $3 \mathrm{C}$ ).

In the usual scenario, where we cannot be sure that shifts come solely from benefit functions, in an effort to identify the cost function as in Figure 3B, an economist is left trying to find an "instrument" (i.e., a variable) that is highly correlated with shifts in the benefit function but not at all correlated with shifts in the cost function. Because all the variation in such a hypothetical perfect instrument would come from shifts of the benefit function, and none from the cost function, it would be possible to use the instruments to statistically map out the cost function. (This is completely analogous to identifying supply or demand functions as discussed in most econometrics textbooks; see for example, Greene 
(2008)). While using an instrument sounds straight-forward, in fact, finding an appropriate instrument is very difficult, and using the wrong instrument introduces a host of statistical problems.

In our case, we have a big advantage. We can explicitly estimate marginal benefit curves, as described in Section 2.1. Therefore, we know exactly when the benefit function is shifting and by how much. This allows us to map out the cost curve with relative confidence that we are observing situations like that depicted in Figure $3 \mathrm{~B}$ (rather than possibly being in a situation like Figure $3 \mathrm{C}$ ).

Even better, because we explicitly know the benefit function, we can map out the cost function in several different settings. First, we can identify the cost curve by observing debt choices made by different firms in the same year. Second, we can identify the cost function based on debt choices (and shifts in the benefit function) for a single firm in several different years (e.g., a firm's benefit function will shift when the federal government changes the tax code and corporate tax rates, therefore also changing the benefit of interest deductions). Or, third, we can estimate the cost functions based on variation in benefit functions both through time and across firms.

In Binsbergen, Graham, and Yang (2010), we describe in detail how we use all three sources of variation to identify the cost curves of debt presented in this paper. As an example of the second approach (i.e., in which we rely on changes in tax rates that occur due to changes in tax law), consider again Alltel, presented in Figure 4. The Tax Reform Act of 1986 reduced the top corporate marginal tax rate, and hence the benefit of interest deductions, from $46 \%$ to $34 \%$ over a three year period. For Alltel, this phase-in resulted in a maximum possible marginal tax rate of $46 \%$ in fiscal year 1986, 39\% in 1987, and $34 \%$ in 1988. Notice how the benefit function shifts downward in Figure 4 as the tax rate falls, reflecting that the benefit of a dollar of deduction falls as the tax burden declines. Because we know the benefit function for Alltel in each year, and we know the chosen amount of debt (depicted as a point on each marginal benefit curve), we can trace out the marginal cost curve as shown with a dotted line in the figure.

There is an important statistical issue that we must deal with in order to map out cost of debt functions. Technically, the cost curve must remain in one place as the benefit curve shifts, in order for us to be able to use variation in the benefit function to identify the cost function 3 That is, the cost curve can not be shifting around at the same time as the benefit function, else we could end up in the ambiguous situation depicted in Figure $3 \mathrm{C}$ C. We deal

\footnotetext{
${ }^{3} \mathrm{~A}$ somewhat subtle issue is that for our approach to provide recommendations for optimal capital structure, it needs to be estimated on a sample of firms that are believed a priori to make optimal choices, or at least that deviations from optimal capital structure are not too large in the estimation sample and are
} 


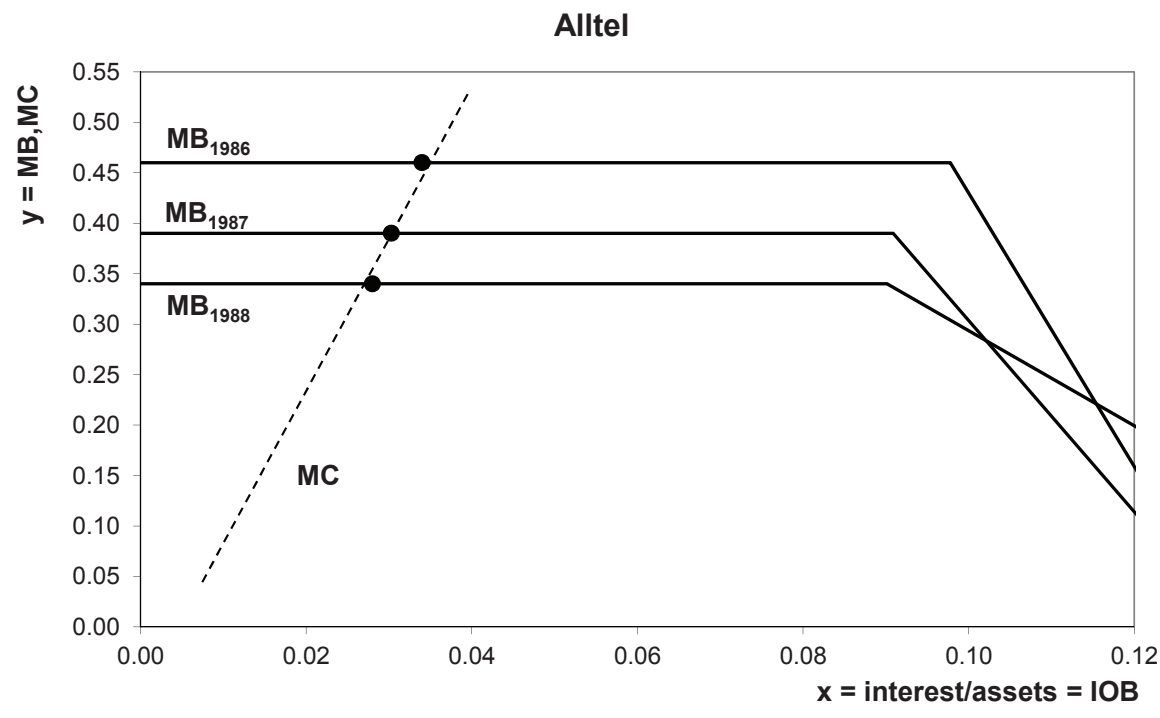

Figure 4: The figure depicts the marginal tax benefit of debt curve for Alltel in 1986, 1987, and 1988. The points on the marginal benefit curves represent the actual interest deducted in those years. Following the Tax Reform Act of 1986 maximum corporate tax rates were reduced from $46 \%$ to $34 \%$ over a three year period, allowing us to trace out the marginal cost curve of debt for Alltel.

with this issue in two different ways. The details are provided in the longer version of this article and briefly in Appendices A and B. We provide intuition of each approach in the next two paragraphs.

First, we use a statistical approach to "hold the cost function constant" as the benefit function shifts. Effectively, we use a multivariate regression in which we "purge" shifts that are attributable to costs. We accomplish this by including "control variables" that are hypothesized in the academic literature to be correlated with the cost of debt: firm size, whether a company's assets are easily usable as collateral, etc. By including these variables in the regression, we statistically hold the cost curve constant in terms of not allowing it to vary for costs captured by these control variables; therefore, the remaining variation is attributable just to shifts in the benefit function.

We separately use a second approach linked to the Tax Reform Act of 1986. The Tax Reform Act (TRA) of 1986 reduced corporate tax rates by $12 \%$ over 1987 and 1988. The 1986 TRA was phased-in in a manner that differentially moved firms with different fiscal year-ends into the new, lower tax regime 4 The 1986 TRA allows us to examine firms in a

averaged away when we consider the full sample. To create a sample of firms that are believed to operate near optimal, we delete firms that are financially distressed and/or constrained in their access to debt markets. In the end, our recommendation of "optimal capital structure" can be thought of as describing how much debt similar firms, with similar characteristics, would use if these firms were not financially constrained or distressed, or faced with some other extraordinary circumstance.

${ }^{4}$ For example, firms with fiscal year-ends in June 1987 had all 12 months of income subject to tax rates 
before-and-after setting, with the "after" reflecting the phased-in implementation of the tax act.

In principle, though the implementations of the two approaches differ, they are both designed to allow us to identify the same cost function, so we expect that they will yield similar results. This is exactly what we find. This is reassuring because it implies that we have zeroed in on the "true" cost of debt function, given that two very different approaches yield similar outcomes.

The first approach (using control variables) is more flexible than the second, and can be applied in many general settings. Additionally, using control variables results in cost of debt curves that are themselves functions of particular firm characteristics. For example, Figure 5 shows two different cost of debt curves, one for a company with assets that can easily be used as collateral (high COL) and another for a company whose assets are not easily collateralizable (low COL). Other than asset collateral, the two firms in the figure have the average values for other firm characteristics (size, growth opportunities, intangible assets, profitability, and dividend policy). $\mathrm{MC}_{\text {lowCOL }}$ is the cost curve for firms that have collateral that is one standard deviation less than the average amount of collateral, and $\mathrm{MC}_{\text {highCOL }}$ represents firms with collateral that is one standard deviation higher than average. The higher intercept on $\mathrm{MC}_{\text {lowCOL }}$ indicates that companies with less collateral face a higher cost of debt, and therefore should use less debt, all else equal. Though not shown in the graph, the cost curve can shift to reflect the effects of the influences of each of the control variables (i.e., firm characteristics) that we include in our estimation procedure.

It is important to highlight just what our cost functions capture. The cost functions of course incorporate the various possible costs of debt (e.g., expected bankruptcy costs, "debt overhang" cost that might discourage a firm from initiating a profitable project because it currently has too much debt, etc.) These costs are reflected in firms' choices, so we do not have to specify which cost is largest or smallest; we let the data and our estimation procedure tell which costs matter the most. Also, recall that the benefit functions capture tax benefits only. Therefore, any nontax benefits show up as "negative costs" in the marginal cost functions that we estimate. This is fine and does not affect our ability to use the cost functions to make recommendations about optimal capital structure.

at the old $46 \%$ tax rate that year. Firms with fiscal year-ends in July 1987 were subject to $\frac{1}{12}$ of the new $34 \%$ tax rate and $\frac{11}{12}$ of the old $46 \%$ tax rate for a blended tax rate of $45 \%$. Firms with fiscal year-ends in August 1987 were subject to $\frac{2}{12}$ of the new tax rate and $\frac{10}{12}$ of the old tax rate, and so on. By June 1988, all firms had switched over to the new regime that had a maximum statutory tax rate of $34 \%$. 


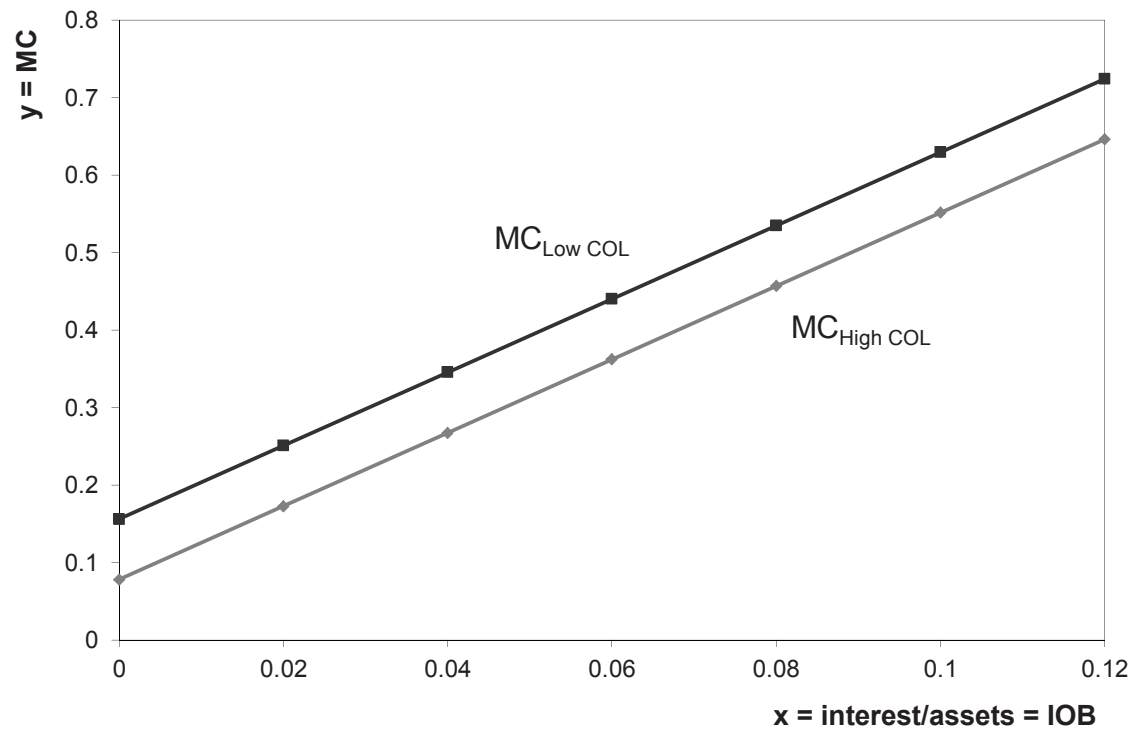

Figure 5: Comparing marginal cost curves for firms with high and low asset collateral (COL). The figure shows the effect of a one standard deviation increase (decrease) in COL when all other firm characteristics remain at the average. Firms with low (high) collateral face a higher (lower) cost of debt.

\subsection{Easy to use Formulas to Estimate The All-in Cost of Debt}

Once we have completed the estimation procedure described in Section 2.2, it is possible for anyone to approximate our estimated cost curves simply by multiplying the estimated coefficients by values for various firm characteristics. We provide the detailed estimation results in Table 1 in Appendix C. The marginal cost of debt for a particular firm $i$ at time $t$ can be determined by:

$$
M C(I O B)=\alpha+\beta * I O B
$$

with

$\alpha=0.117-0.039$ COL +0.015 LTA -0.018 BTM -0.024 INTANG $+0.080 C F+0.063$ DDIV

$\beta=4.733$

where each of the firm characteristics, except DDIV, is standardized (the mean is subtracted, with the result divided by the standard deviation) using the data provided in the table below. DDIV is a variable that contains a value of 1 for firms that pay dividends and a value of 0 for non-dividend paying firms 5

\footnotetext{
${ }^{5}$ We standardize the control variables in our estimation procedure so that the estimated coefficients can be interpreted with an one standard deviation interpretation. That is, a -0.039 coefficient means that a firm with COL one standard deviation higher (lower) than the average will face a marginal cost curve with an intercept 0.039 lower (higher) than the average. This is presented graphically in Figure 5 as $\mathrm{MC}_{\text {highCOL }}$ $\left(\mathrm{MC}_{\text {lowCOL }}\right)$.
} 


\begin{tabular}{l|ccccc}
\hline \hline & COL & LTA & BTM & INTANG & CF \\
\hline Mean & 0.493 & 5.089 & 0.766 & 0.061 & 0.094 \\
Std. Dev. & 0.231 & 2.176 & 0.631 & 0.109 & 0.149 \\
\hline \hline
\end{tabular}

COL is collateral and is the sum of physical assets and inventories divided by total book assets for a firm. LTA is the log of total book assets. BTM is the ratio of book equity to market equity. INTANG is the ratio of intangible assets to total book assets. CF is net cashflows over total book assets. Finally, IOB is interest expense over total book assets for a firm and is the measure of debt intensity.

The coefficients in our estimated cost of debt function are consistent with implications from previous capital structure research. For example, Frank and Goyal (2009) show that firms use less debt when they have less collateral. Our estimated coefficients indicate that the cost of debt is high when firms have fewer collateralizable assets. Given that a high cost of debt implies that, all else equal, a firm should use less debt, the directional effect of collateral on our estimated cost curves is consistent with existing literature, which is reassuring.

To see how to implement equation (11) above, let's take the example of Barnes \& Noble in 2006. The table below reports both the raw and standardized firm characteristics for Barnes \& Noble in 2006:

\begin{tabular}{l|cccccc}
\hline \hline & COL & LTA & BTM & INTANG & CF & DDIV \\
\hline Raw & 0.676 & 7.911 & 0.459 & 0.110 & 0.133 & 1 \\
Standardized & 0.792 & 1.297 & -0.486 & 0.447 & 0.259 & 1 \\
\hline \hline
\end{tabular}

The standardized value for COL is 0.792 , which equals collateralizable assets as a proportion of total assets for Barnes \& Noble in 2006 (0.676), minus the mean COL for the sample (0.493) from the previous table, with the difference divided by the sample standard deviation of COL (0.231). The standardized values for the other firm characteristics are similarly calculated. We plug the standardized firm characteristics into equation (11) to get a marginal cost curve for Barnes \& Noble in 2006: $M C=0.188+4.733 * I O B$. Figure 6A depicts this marginal cost curve for Barnes \& Noble in 2006.

Knowing the entire marginal cost curve of debt (as in Figure 6A) allows us to determine the marginal cost of debt for any level of debt that Barnes \& Noble might choose. To determine Barnes \& Noble's marginal cost of debt for its actual amount of debt in 2006, we plug in the firm's actual interest/assets ratio (IOB) into the MC function we just estimated. In 2006, Barnes \& Noble's interest to book assets ratio is 0.036 (i.e., interest expense is equal to $3.6 \%$ of book assets). This implies that if Barnes \& Noble were to use debt that produced 

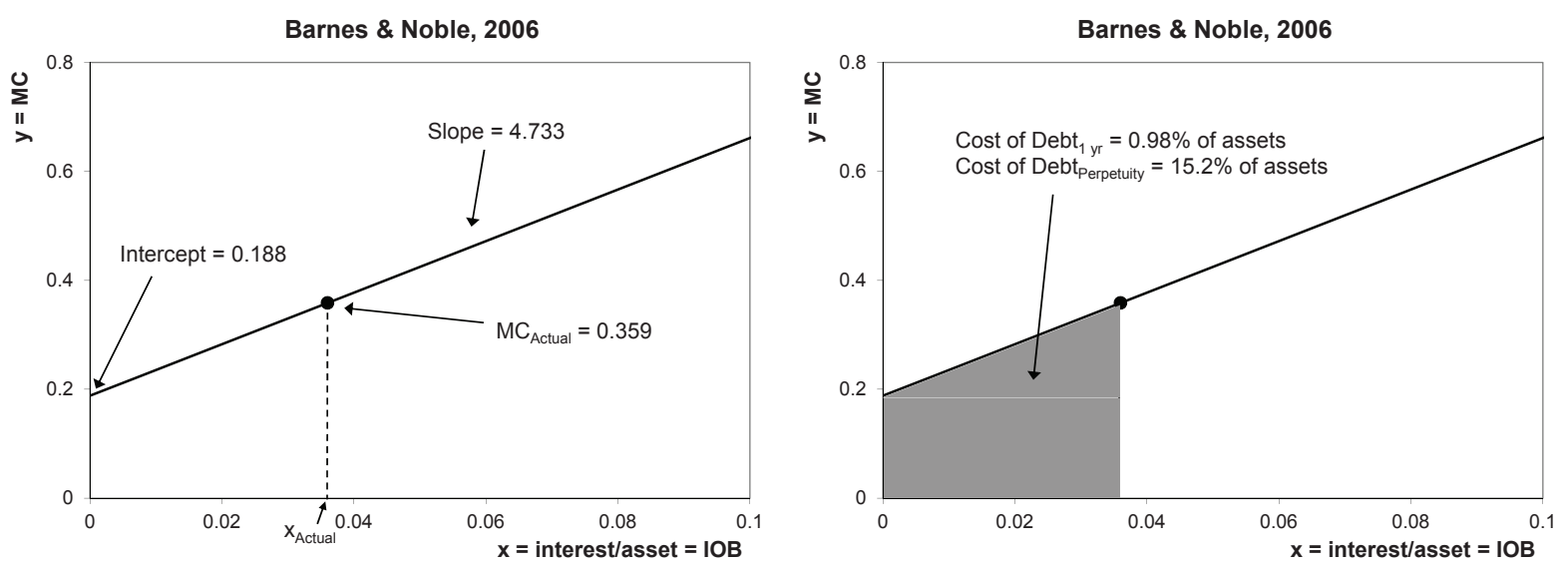

Figure 6: A) Marginal cost curve for Barnes \& Noble in 2006. The point represents actual debt usage in 2006. B) The one year cost of debt is the area under the MC curve. The cost of debt in perpetuity is the one year cost of debt discounted at the Moody Baa rate.

another dollar of interest expense, the all-in cost of that additional extra dollar of interest would be $\$ 0.359(\approx 0.188+4.733 * 0.036)$. This cost represents the sum of expected costs of bankruptcy should it occur, the quantification of agency costs that occur when there are conflicts between difference classes of security-holders, and any other cost of debt 6 Note that we can use the cost curve to estimate the cost of debt for any possible amount of debt, not just the actual amount.

Armed with marginal cost functions calculated using equation (11), we can also estimate the total cost of using a certain amount of debt. Note that previously we calculated the marginal cost of debt, i.e., the incremental cost of debt for moving from $\mathrm{X}$ amount of debt to $\mathrm{X}+1$ amount of debt. Now we calculate the (total) cost of debt, i.e., the cost of debt for having every dollar of debt up to amount $\mathrm{X}$; this is the cost of moving from 0 to 1 dollar of debt plus the cost of moving from 1 to 2 dollars of debt, etc., up to X amount of debt. For a particular debt level, for a particular firm in a particular year, the one year cost of debt equals the area under the cost curve up to that amount of debt. Continuing with Barnes \& Noble, the one year cost of debt in 2006 is the shaded region in Figure $6 \mathrm{~B}$ which is equal to about $0.98 \%$ of asset value or, equivalently, $0.69 \%$ of firm value 7 To determine the (overall, capitalized) cost of debt, we need to determine the present value of the cost of debt in all future years. We calculate this using the perpetuity formula and discounting at Moody's Baa rate (or a comparable discount rate). For Barnes \& Noble, this approach implies a cost

\footnotetext{
${ }^{6}$ These marginal costs may differ from coupon rates because they not only capture expected bankruptcy costs, but all costs (and negative benefits) that managers perceive and trade off against tax benefits as they choose their optimal capital structure.

${ }^{7}$ In this paper, we define firm value as total book value minus book equity plus market equity.
} 


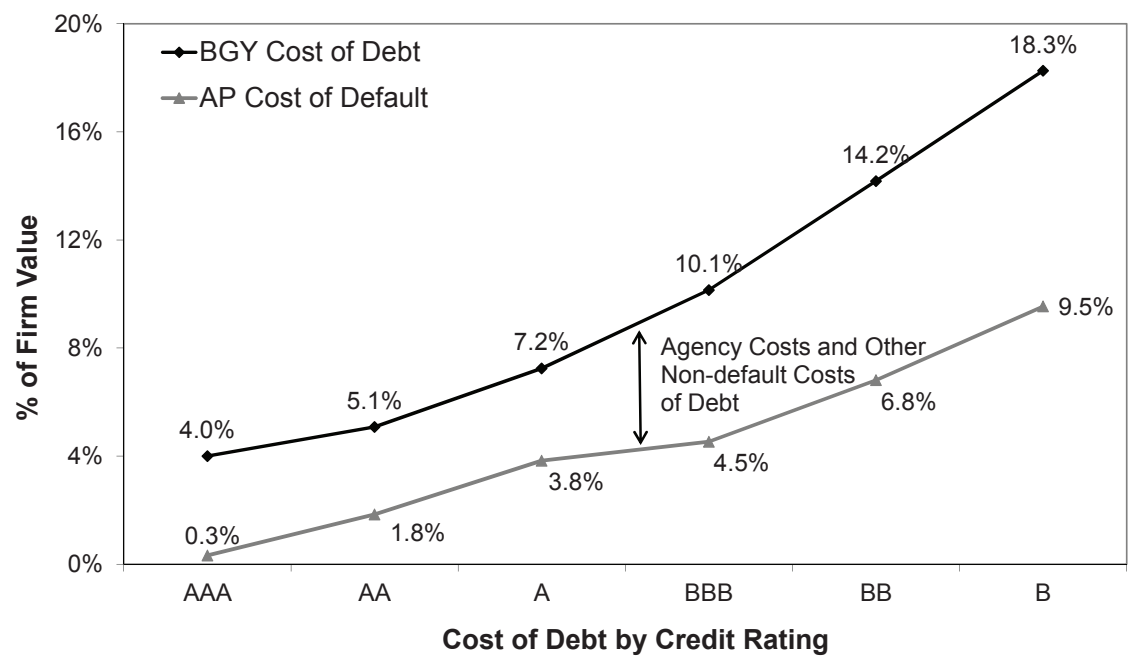

Figure 7: The (total) cost of debt as a percentage of firm value by S\&P credit rating groups: AAA, AA, A, $\mathrm{BBB}, \mathrm{BB}$, and $\mathrm{B}$.

of debt equal to $15.2 \%$ of asset value (discounting at rate of $6.5 \%$ ), equivalent to $10.6 \%$ of firm value. This means that if debt were to suddenly have zero cost, and the firm used the same amount of debt, the market value of Barnes \& Noble would increase by $10.6 \%$.

In addition to calculating firm-by-firm costs of debt, we can calculate the cost of debt for any set of firms, either through time (e.g., the cost of debt for Barnes \& Noble from 2000 to 2006), across firms (e.g., the cost of debt for investment grade firms in 2006), or any combination of the two. Figure 7 presents the average cost of debt for AAA, AA, A, $\mathrm{BBB}, \mathrm{BB}$, and B rated firms over the period 1980 to 2009. Given the small amount of debt that they use and their strong credit-worthiness, AAA rated firms face a cost of debt of about $4.0 \%$ of firm value ("BGY Cost of Debt"). Progressively increasing, as expected, AA, $\mathrm{A}, \mathrm{BBB}, \mathrm{BB}$, and $\mathrm{B}$ rated firms face capitalized costs of debt of about $5.1 \%, 7.2 \%, 10.1 \%$, $14.2 \%$, and $18.3 \%$ of firm value, respectively.

Almeida and Philippon (2007) argue that firms are more likely to face financial distress in bad times and this should be reflected in the cost of default. In addition to the overall cost of debt, Figure 7 presents the Almeida and Philippon (2007) cost of default ("AP Cost of Default") by credit rating. Our cost of debt estimates are larger than the Almeida and Philippon calculations because our numbers include more than just default costs. Based on this comparison, expected default costs of debt amount to approximately half of the total costs of debt. In other words, agency and other non-default costs make up half of the cost of debt, roughly equal in magnitude to default costs. 
Barnes \& Noble, 2006

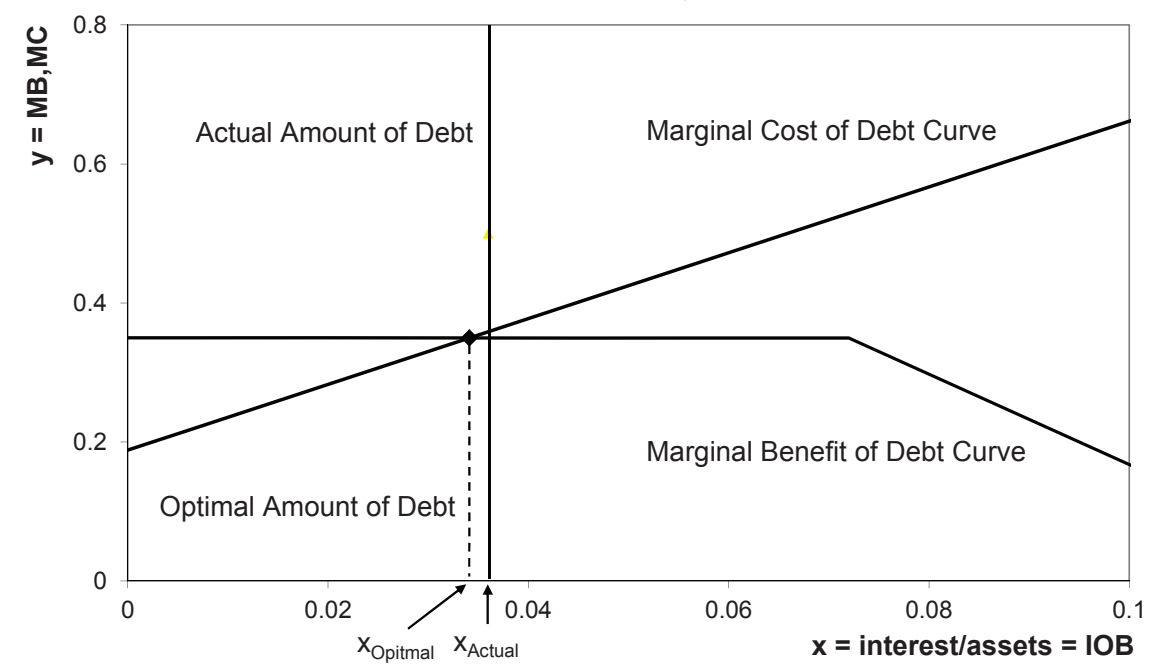

Figure 8: Marginal benefit and marginal cost curves of debt for Barnes \& Noble in 2006. The solid vertical line reflects actual debt usage and the dotted line from the intersection of the two curves reflects the optimal debt level for the firm. In 2006, Barnes \& Noble operated near its model implied optimal capital structure.

\section{The Optimal Amount of Debt Financing}

Now that we have both firm-specific marginal benefit and marginal cost curves, we can determine firm-specific optimal capital structure. Furthermore, we can use our curves to quantify the gross benefit of debt, the cost of debt, and the net benefit of debt at any debt level, including optimal debt levels.

\subsection{Determining Optimal Capital Structure}

Using the benefit and cost functions, we can determine the optimal amount of debt for any given firm. This optimal debt choice occurs where the marginal benefit and cost curves intersect. For example, we again consider Barnes \& Noble. In 2006, Barnes \& Noble's chosen amount of debt is near its model-recommended capital structure because its actual interest/assets ratio occurs almost exactly where its cost and benefit functions intersect (see Figure 8).

Not all companies operate near their optimal capital structures. Consider Six Flags, Inc in Figure 9A. Six Flags is overlevered in 2006 because its actual debt usage is over three times the recommended amount of debt 8

\footnotetext{
${ }^{8}$ Due to aggressive expansion in the 1990s, Six Flags accumulated over $\$ 2$ billion in debt by 2006 . To pay down some of its debt, Six Flags sold several of its theme parks to Parc Management in early 2007 for $\$ 312$ million.

Source: http://www.washingtonpost.com/wp-dyn/content/article/2007/01/11/AR2007011100602.html
} 

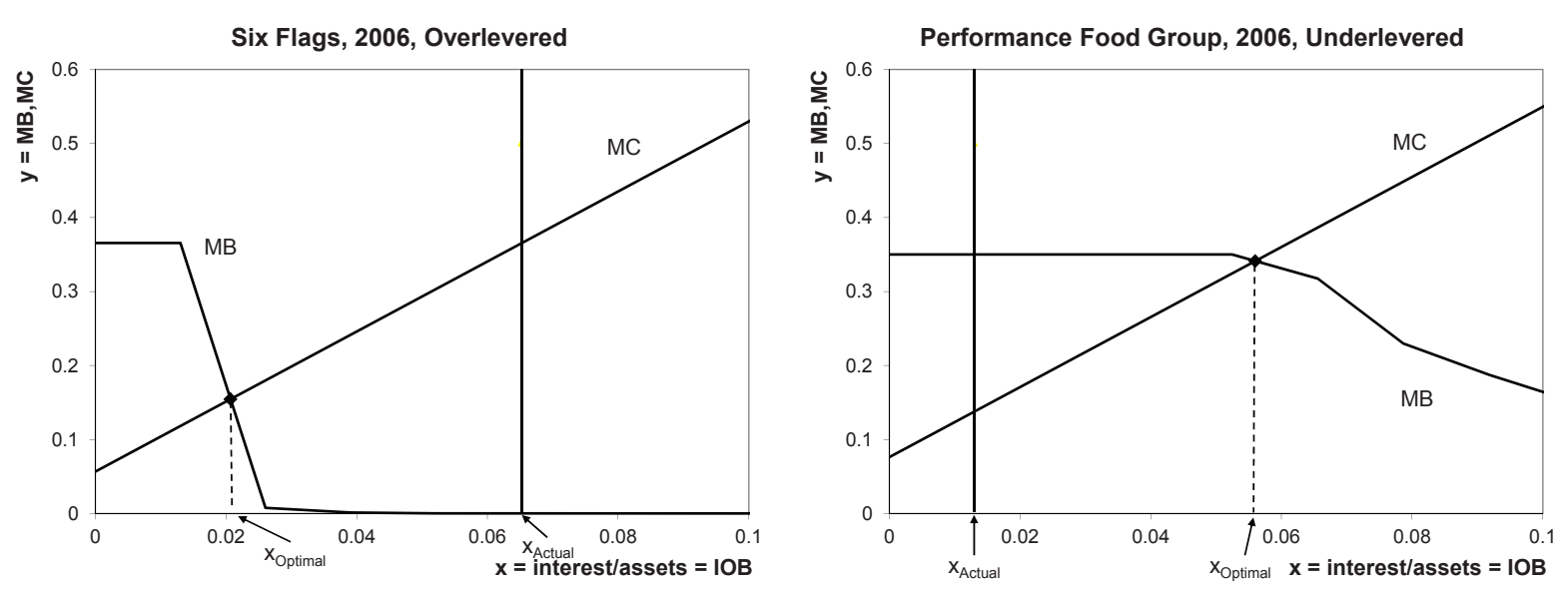

Figure 9: A) Marginal benefit and marginal cost curves of debt for Six Flags in 2006. In 2006, Six Flags was overlevered relative to its model implied capital structure. B) Marginal benefit and marginal cost curves of debt for Performance Food Group in 2006. In 2006, Performance Food Group was underlevered relative to its model implied capital structure. Interestingly, in 2008 Performance completed a highly levered transaction that increased its IOB to very near $x_{\text {Optimal }}$.

It is worth spending an extra minute interpreting just what we mean when we say a firm is overlevered. We make an optimal capital structure recommendation based on the marginal cost and marginal benefit of debt for a given firm. That firm's cost function is determined based on coefficients that we estimate on a sample of firms that are likely to have made optimal or near-optimal capital structure choices. Therefore, when we say that Six Flags is overlevered, we mean that it has more debt than do similar companies (i.e., companies with similar asset collateral, size, cash flow, etc.) that are thought to be making optimal choices. The debt choices of these similar firms are captured in the coefficients of the estimated marginal cost curve, as presented in equation (1) in the previous section. Therefore given that Six Flags has more debt than is recommended by our cost and benefit estimates, Six Flags is "overlevered" relative to these other companies.

Companies can also be underlevered. For example, consider Performance Food Group, Co. in Figure 9B. Performance Food Group is underlevered because its actual amount of debt is about one-fifth of the recommended debt usage in 2006. As before, when we say a firm is underlevered, we mean that is has less debt than do companies with similar characteristics (size, asset collateral, etc.) that are thought to be making optimal choices.

In January 2008, Blackstone Group LP and Wellspring Capital Management LLC agreed to acquire Performance Food Group for $\$ 1.3$ billion 9 To support this buyout, on April 30 , 2008 Performance Food Group drew $\$ 1.1$ billion of debt from a revolving line of credit at a

\footnotetext{
${ }^{9}$ Source:

http://www.bloggingbuyouts.com/2008/01/18/blackstone-pays-1-3-billion-for-performance-food-group/
} 
Barnes \& Noble, 2006

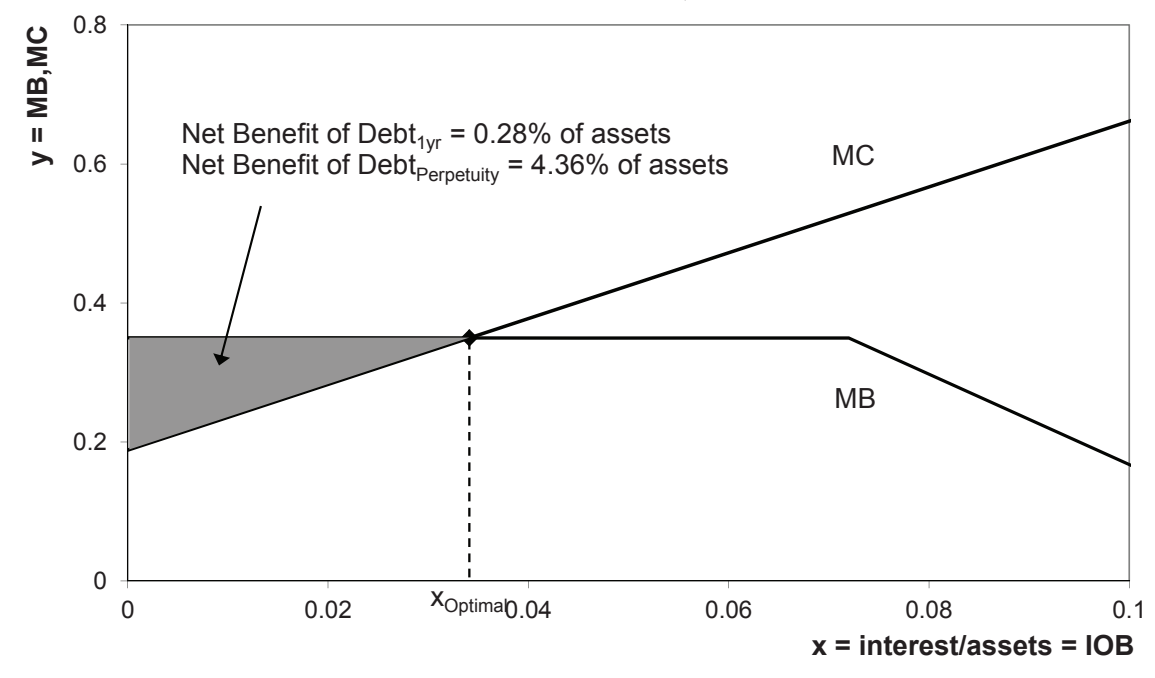

Figure 10: Net benefit of debt for Barnes \& Noble in 2006. The net benefit of debt is the difference between the area under the marginal benefit of debt and the area under the marginal cost of debt.

rate of LIBOR +225 . This translates to about $\$ 58.6$ million in interest or a IOB of $4.31 \%$ of book assets. Combined with an existing IOB of 1.31\% for Performance Food Group in 2006, the leveraged buyout increased Performance Food Group's 2006 IOB to 5.62\%. Compared to our model implied optimal capital structure of 5.65\% IOB in Figure 9B, this would suggest that the leveraged buyout moved Performance Food Group almost exactly to its optimal debt ratio.

\subsection{Firm Value Gain or Loss Due to Debt Financing}

By determining the area under the marginal benefit curve, we can quantify the gross tax benefit of debt (as shown in Figure 2). By measuring the area under the marginal cost curve, we can quantify the cost of debt (as shown in Figure 6B). For any given firm, the difference between the gross benefit of debt and the cost of debt equals the net benefit of debt. For example, in Figure 10, the net benefit of debt for Barnes \& Noble is $0.3 \%$ of asset value for 2006 and $4.3 \%$ of asset value when capitalized. (Note that for Barnes \& Noble in 2006, 4.3\% of asset value is equivalent to $3.0 \%$ of total firm value). This means that $3.0 \%$ of Barnes \& Noble's firm value (common stock plus debt) comes from the benefits of debt financing (such as interest tax deductions), net of all costs. In other words, Barnes \& Noble's firm value would be $3.0 \%$ less if it did not use debt.

Let's turn back to the overlevered case of Six Flags in 2006 (see Figure 11A). Rather than adding $6.8 \%$ of firm value at the optimal amount of debt (area A in Figure 11A), Six Flags' overleverage is reducing firm value by $9.6 \%$ (area A minus area B in Figure 11A). At 

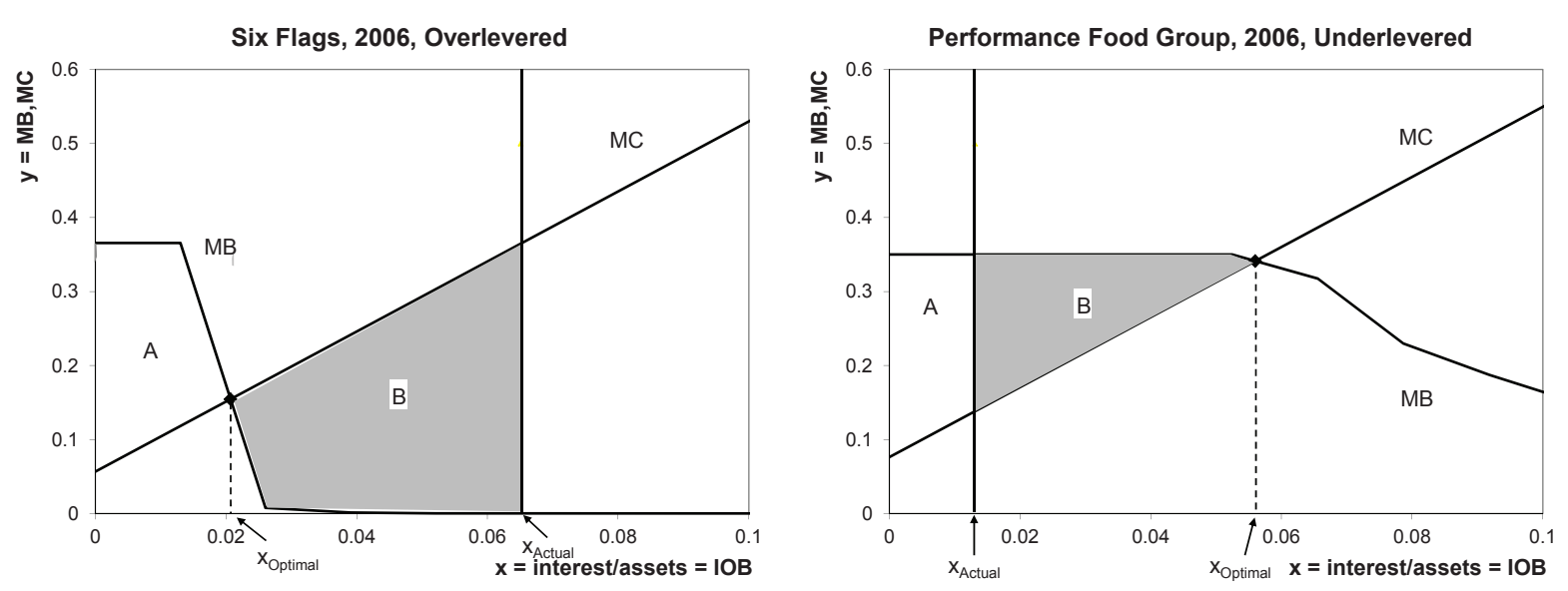

Figure 11: A) Net benefit of debt for Six Flags in 2006 is the difference between areas A and B. Six Flag faces a negative net benefit of debt due to overlevering. B) Net benefit of debt for Performance Food Group in 2006 is the sum of areas A and B. Performance Food Group leaves money on the table by not taking advantage of area $\mathrm{B}$ when underlevering.

the actual level of debt usage, Six Flag's capitalized gross benefit of debt is about $10.8 \%$ of firm value. However, the cost of debt is larger, about $20.4 \%$ of firm value. This results in a capitalized net benefit of $-9.6 \%$ of firm value, the difference between areas A and B in Figure 11A. That is by operating above the recommended debt level, Six Flag's market value is reduced by $9.6 \%$.

Let's turn now to our underlevered example, Performance Food Group, in 2006 (presented in Figure 11B.) At the actual level of debt usage, Performance Food's gross benefit is $6.4 \%$ of firm value in perpetuity and the cost of debt is $1.9 \%$, resulting in a net benefit of debt equal to $4.4 \%$ of firm value (area A). Although Performance Food Group's debt policy adds to market value, the company is leaving money on the table in terms of unexploited net benefits of debt (area B in Figure 11B). That is, by increasing leverage to the recommended level, Performance Food Group can further increase its net benefit of funding choice. At the optimal capital structure, Performance Food Group would face a capitalized gross benefit equal to $27.1 \%$ of firm value and a cost of $16.2 \%$. This results in a capitalized net benefit of $10.9 \%$ of firm value, the sum of areas A and B in Figure 11B.

Recall that Six Flags faces a net loss of $9.6 \%$ of firm value in perpetuity in 2006 when it could have had a net benefit of $6.8 \%$ by operating at the optimal capital structure recommended by our model. This implies that the cost of "being out of equilibrium" or the cost of not optimizing is $16.4 \%(=6.8 \%-(-9.6 \%))$ of firm value (as depicted by area B in Figure 11A). In Six Flag's case, this is also the cost of being overlevered. Levering correctly would increase Six Flag's market value by $16.4 \%$. 

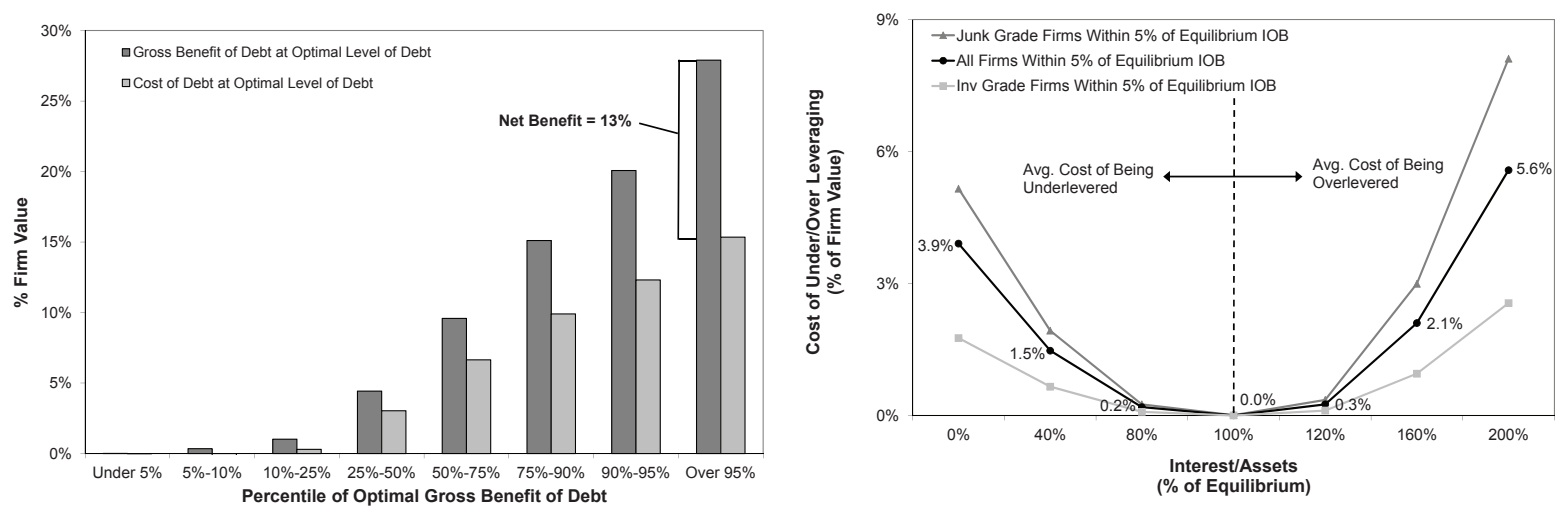

Figure 12: A) Histogram of the gross benefit and cost of debt for firms sorted on their gross benefit of debt at optimal debt levels. B) For firms operating near optimal capital structure, the cost of being underlevered or overlevered if the firm were to hypothetically change its interest/book asset ratio to be X\% of optimal.

In contrast, Performance Food Group experiences a net benefit of $4.4 \%$ of firm value in 2006, when it could have had a net benefit of $10.9 \%$ by operating at the optimal capital structure. This yields a cost of being out of equilibrium, or in this example the cost of underlevering, equal to $6.5 \%(=10.9 \%-4.4 \%)$ of firm value (as depicted by area $\mathrm{B}$ in Figure 11B). This means that Performance could increase firm value by $6.5 \%$ if it used debt optimally 10 Note that the cost of Performance being underlevered is much smaller than the $16.4 \%$ cost of overleverage that Six Flag faces, despite both firms having actual IOBs that deviate from the model-implied optimum by approximately 0.044 .

More broadly, we estimate the optimal and chosen amount of debt for all firms (with the needed data) on Standard and Poor's Compustat database between 1980 and 2009, using the same methods that we used for Barnes \& Noble, Six Flags, and Performance Food Group. In this analysis, we include the financially constrained and financially distressed firms that we removed from the initial estimation of the marginal cost curve. This allows us to determine the net benefit of debt and the cost of being out of equilibrium for any given firm in any given year. Figure 12A presents the histogram of the gross benefit and cost of debt for firms sorted by their gross benefit of debt at optimal debt levels. We see that firms with the highest gross benefit of debt (firms with gross benefit of debt above the 95th percentile) face an average net benefit of debt equal to $13 \%$ of firm value.

Figure 12B graphs the costs of being underlevered or overlevered for the typical nearoptimal firm if it hypothetically had X\% of its optimal leverage. Notice the asymmetry in

\footnotetext{
${ }^{10}$ Recall from the previous section that Performance's LBO raised leverage to almost exactly the amount recommended by our model. This means that the financing aspect of the LBO raised Performance's firm value by $6.5 \%$ (see Figure11). There may have been other benefits, such as operating efficiently, not captured in our estimate.
} 

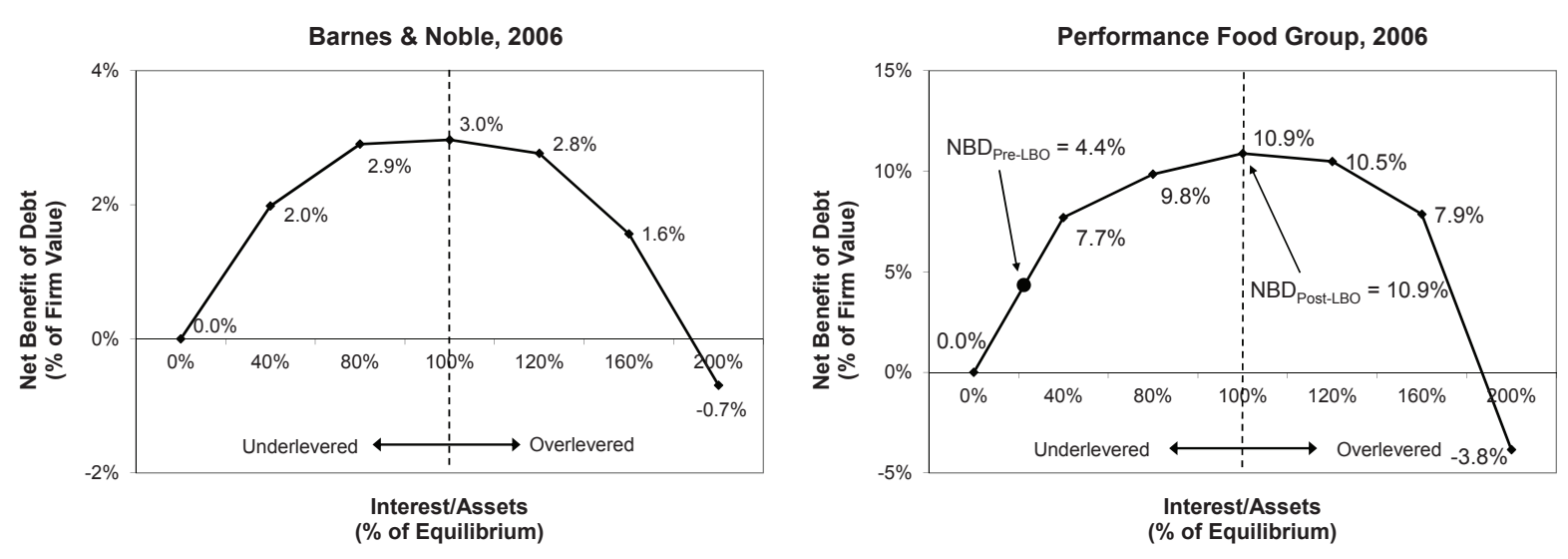

Figure 13: A) Hypothetical net benefit of debt for Barnes \& Noble in 2006 depicting the value gained from capital structure. The value graph is hump-shaped because capital structure adds value up to the optimal point, then declines after that point. B) Hypothetical net benefit of debt for Performance Food Group in 2006 depicting the value gained from capital structure.

that costs for overlevering are higher on average than costs for underlevering. For example, compare the cost of deviation if a firm is hypothetically at $120 \%$ of its optimal (overlevered) to if it is hypothetically at $80 \%$ of its optimal (underlevered). This asymmetry is magnified for firms with junk-grade debt and decreased for firms with investment-grade debt. The asymmetrically higher cost of overleverage helps explain why some firms choose suboptimal amounts of debt.

Most finance textbooks present a stylistic graph that shows how much a hypothetical firm could add to its market value by using various amounts of debt in its capital structure. Given that we estimate firm-specific marginal benefit and cost curves, we can create such a "value added from capital structure" graph for any given firm. One of the big unanswered questions in corporate finance is whether this graph is "steep." For example, how much value would be lost if a firm were to use $20 \%$ too little debt, or $20 \%$ too much debt? We can use our estimates and real world data to answer these questions.

Figure 13A plots the net benefit of debt for Barnes \& Noble if the company were to hypothetically use different amounts of debt in 2006. That is, this is the "value gained from capital structure" graph for Barnes \& Noble. In 2006, optimal capital structure increases Barnes \& Noble's firm value by $3.0 \%$ at the optimum financing choice - said differently, if Barnes \& Noble were to stop using debt, its firm value would fall by $3.0 \%$ (ignoring possible "signaling" and other effects associated with financing announcements).

Figure 13B plots the net benefit of debt for Performance Food Group. In this case, using the correct amount of debt adds $10.9 \%$ to the market value of Performance. In 2006, Performance was underlevered and used only one-fifth of its optimal amount of debt (denoted 


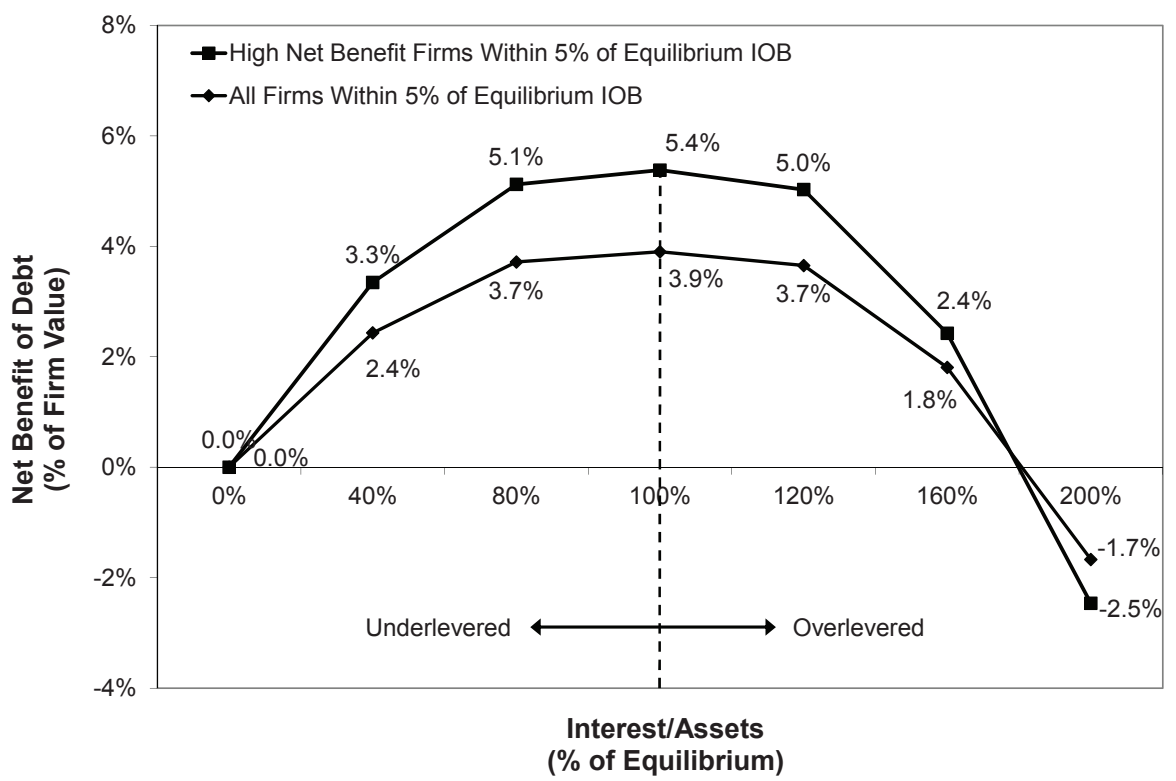

Figure 14: Hypothetical net benefit of debt (gross benefit minus cost of debt) for firms within 5\% of their optimal IOB and for firms with high net benefit of debt (firms with net benefit above 50th percentile). The graph shows for the typical near-equilibrium firm, optimal capital structure adds about $3.9 \%$ to firm value. For a firm with high benefits of debt, optimal capital structure increases firm value by about $5.4 \%$ of firm value. These capital structure value functions are fairly flat for movements within $\pm 20 \%$ of the optimal level, but fall off steeply for larger deviations.

by a large dot in the figure). Figure 11B indicates that using too little debt cost Performance $6.5 \%$ of firm value. Recall from our earlier discussion that Performance completed an LBO in 2008 that placed the firm more or less in equilibrium. Figure 13B makes it clear that the LBO added to market value by making a financing choice near the optimum.

By comparing Figure [13 A and Figure $13 \mathrm{~B}$, we see that the value function is sometimes steep (suboptimal capital structure is more costly for Performance, in Figure 13B) and sometimes it is relatively flat (Barnes \& Noble would not lose much value if it were to deviate within a reasonable range from its optimum). In Figure 14 we present the "value gained from capital structure" for the typical firm in our sample, among all firms that operate within $\pm 5 \%$ of model-implied optimal debt usage. Our analysis indicates that for the typical firm, optimal capital structure increases firm value by 3.9\%, though as mentioned earlier, this number is more than $13 \%$ for one in twenty firms (see Figure [12A). The value function is fairly flat if a typical firm were to hypothetically operate within $\pm 20 \%$ of optimal. However, the value of capital structure falls off fairly steeply if the debt choice were to be more than $20 \%$ from ideal. Consistent with our previous analysis, a capital structure choice in which debt usage is more than $80 \%$ larger than optimal would actually reduce firm value. 

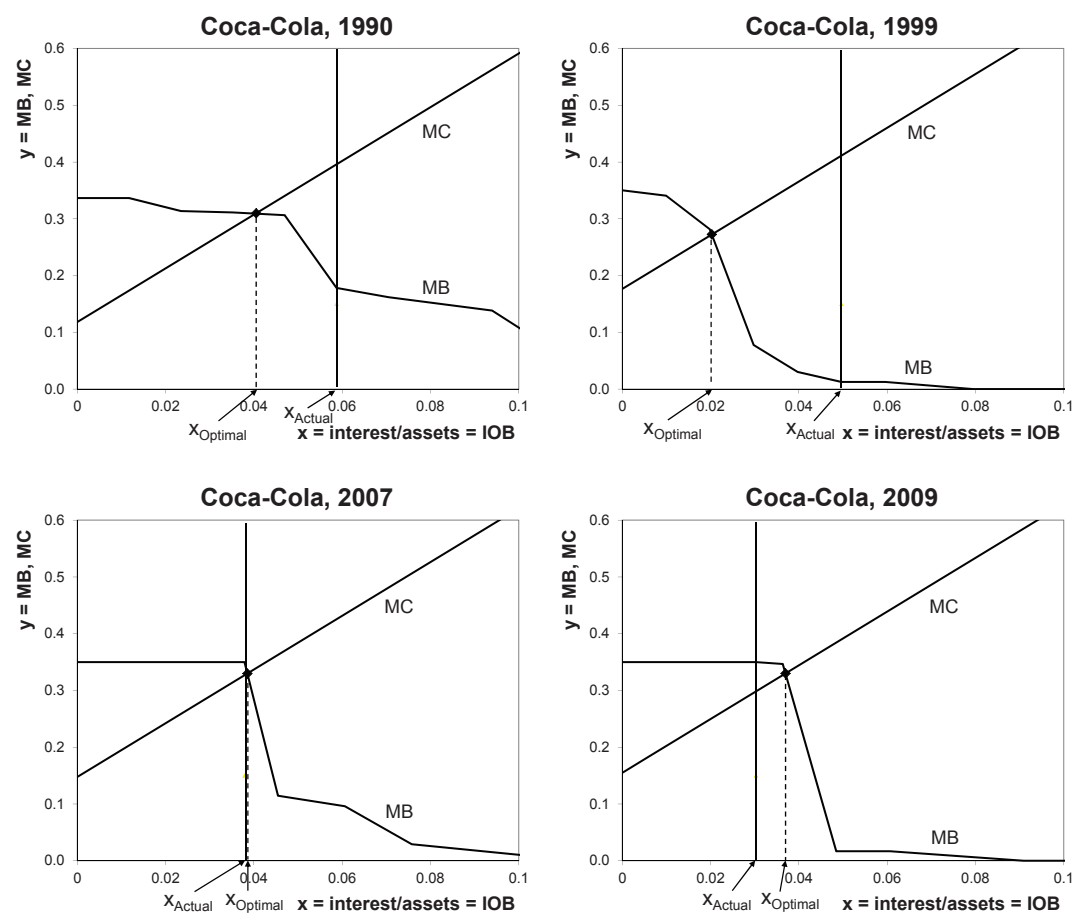

Figure 15: Marginal benefit and marginal cost curves for Coca-Cola in 1990, 1999, 2007, and 2009. The solid vertical line reflects the actual debt usage. The dotted vertical line reflects the optimal capital structure.

\section{Additional Case Studies}

In previous sections, we demonstrated how to use marginal benefit and marginal cost curves of debt to examine optimal capital structure for Barnes \& Noble, Six Flags, and Performance Food Group. Our analysis showed that Barnes \& Noble more or less used its model recommended debt level. Six Flags used too much debt, and Performance Food Group used too little in 2006. In this section, we examine five additional case studies of companies that altered their financing mix relative to their optimal capital structure.

\subsection{Coca-Cola}

It is interesting to contemplate whether firms can be successful without choosing optimal capital structure in a given year. Coca-Cola is an example of a successful firm that deviates in some years from the optimal capital structure recommended by our model. Figure 15 depicts optimal capital structure for Coca-Cola in 1990, 1999, 2007, and 2009. Based on our analysis, the company is overlevered in 1990 (actual debt is more than the model implied optimum), using about half-again as much debt as recommended by the model (the point where the marginal benefit and cost curves intersect). The company is even more overlevered in 1999, 
now having about twice as much debt as our model implies is optimal. Our estimates imply that if Coke had maintained this degree of debt usage, being overlevered would reduce its value by about $7.2 \%$, or $\$ 107.7$ million. We also note that Coca-Cola's overall market value tripled from 1990 to 1999, indicating that the company's operating performance was stellar, notwithstanding the extra debt usage. (Our analysis suggests that Coca-Cola's value could have been even greater in 1999 - \$107.7 million greater.) By 2007, Coca-Cola decreased

leverage, operating at the optimal capital structure. By 2009, Coca-Cola continued to decrease its leverage, becoming slightly underlevered.

What can we learn from the case of Coca-Cola? First, a company can potentially make excellent operating decisions even if its capital structure is suboptimal in a given year. Second, companies may take a long-run perspective on capital structure, deviating in a given year if having more (or less) debt than optimal facilitates operating choices in the short-run. For example, a company could use "too little debt" in a given year because it is saving its debt capacity for a planned expansion one or two years in the future. Third, our model makes predictions about how much debt a company (like Coca-Cola) should use relative to other firms with similar characteristics that appear to make optimal choices. Management for a particular firm may argue that special circumstances dictate that their firm choose a different capital structure than implied by the model - our view is that if the value-consequences of such leverage choices are large, management should be prepared to explicitly defend why they deviate from the optimal leverage choice. This is particularly true when a firm uses substantially more debt than the model-implied optimum.

\subsection{Pepsico}

Figure 16 depicts optimal capital structure for Pepsico in 1990, 1999, 2007, and 2009. Like Coca-Cola, Pepsico is a large, well-known beverage products company with large cash flows, intangible assets, and consistent dividend payments. The company is overlevered in 1990 with about twice as much debt as recommended. Should Pepsico's 1990 capital structure remain in place indefinitely, being overlevered would reduce Pepsico's firm value by about $1 \%$ of firm value, or $\$ 208.5$ million. By 1999, Pepsico was still overlevered, but much less so than Coca-Cola. At Pepsi's 1999 capital structure, the cost of being overlevered is just $0.05 \%$, or $\$ 29.3$ million. By 2007 , the company chooses a leverage equal to our model-implied optimum and remains near equilibrium in 2009. 

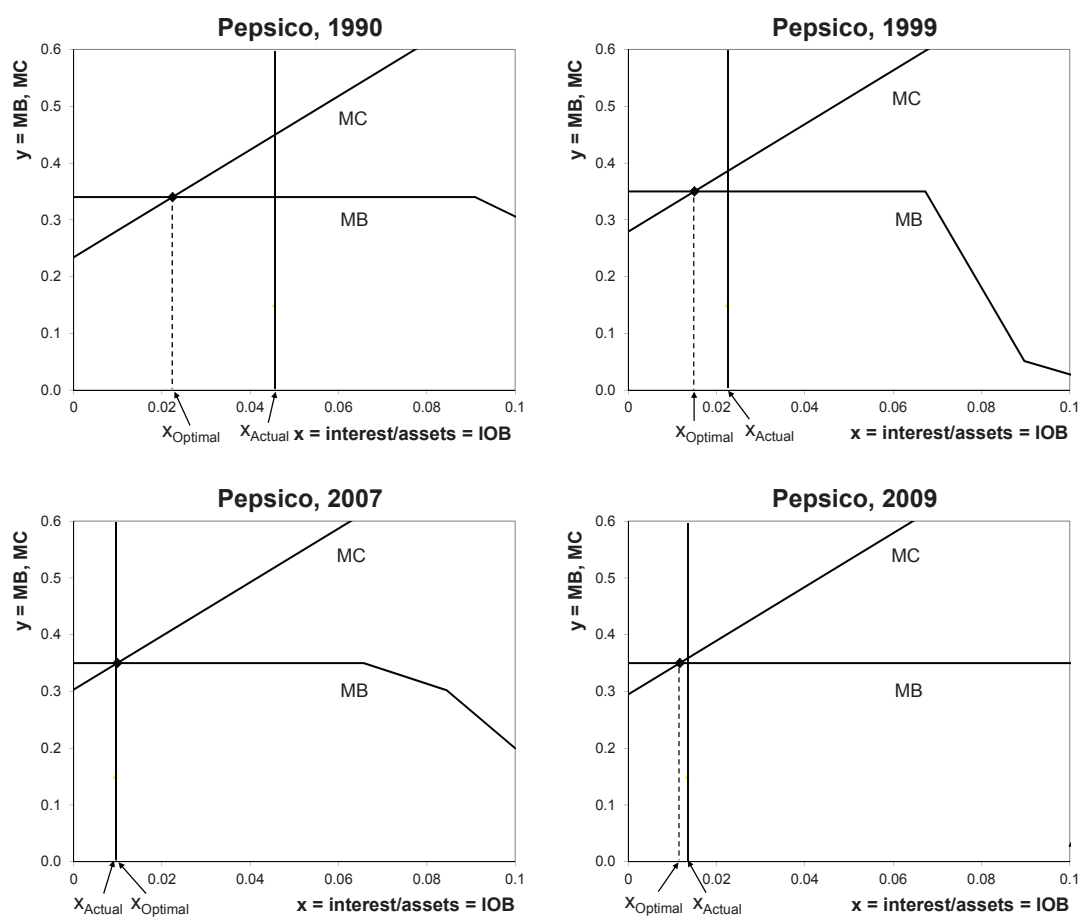

Figure 16: Marginal benefit and marginal cost curves for Pepsico in 1990, 1999, 2007, and 2009. The solid vertical line reflects the actual debt usage. The dotted vertical line reflects the optimal capital structure.

\subsection{Black \& Decker}

Figure 17 depicts the optimal capital structure for Black \& Decker in 1990, 1999, 2007, and 2009. Black \& Decker is a large firm that pays dividends and has stable sales. Relative to the model implied debt ratio, Black and Decker is overlevered in 1990. This excessive debt is related to Black and Decker's highly levered acquisition of Emhart Corporation in 1989. In the mid 1990s, Black and Decker issued equity for the purpose of paying down its debt 11 Thus by 1997, Black and Decker's actual leverage had decreased and the firm had moved closer to its model-implied optimal debt ratio. In 2007, the firm is in equilibrium as its actual IOB coincides with the model implied IOB. By 2009, Black and Decker continued to reduce its leverage ratio, leaving it slightly underlevered.

\subsection{Home Depot}

Figure 18 depicts the optimal capital structure for Home Depot in 1990, 1999, 2007, and 2009. Home Depot is a large home retail company that consistently pays dividends and has relatively high cash flows. We see that in 1990, Home Depot chooses an actual debt level that is slightly higher than the recommended debt level. In 1999, Home Depot becomes

\footnotetext{
${ }^{11}$ Source: http://query.nytimes.com/gst/fullpage.html?res=9E0CE3DB1E3CF930A25750C0A964958260
} 

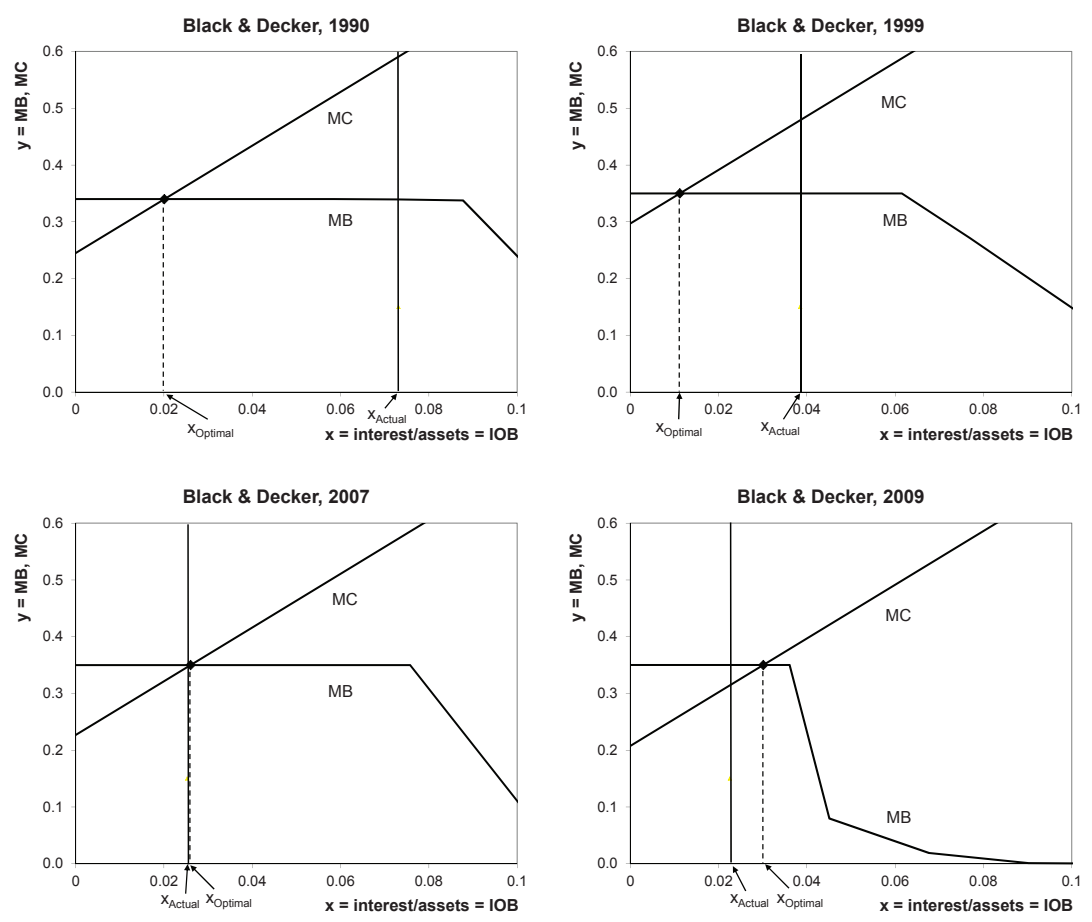

Figure 17: Marginal benefit and marginal cost curves for Black \& Decker in 1990, 1999, 2007, and 2009. The solid vertical line reflects the actual debt usage. The dotted vertical line reflects the optimal capital structure.

slightly underlevered. In 2007, the firm has almost exactly the optimal amount of debt. By the end of fiscal year 2009, Home Depot is again slightly underlevered.

\subsection{Walmart}

Just as firms can change from being suboptimally levered to being (close to) optimally levered, firms can also move further out of equilibrium. Figure 19 presents the optimal capital structure for Walmart in 1990, 1999, 2007, and 2009. Walmart is a large retail chain with consistent cash flows, sales, collateral, intangible assets, and dividend payments. In 1990, Walmart operated close to its model implied debt level. In 1999, Walmart's actual debt was two-thirds of its recommended debt. Throughout the 2000s, Walmart remains underlevered from one-half to two-thirds of its model implied leverage ratio. If the 2009 situation were to continue indefinitely, the capitalized cost of underlevering would reduce Walmart's market value by about $0.16 \%$ of firm value, or $\$ 481.0$ million, from leaving money on the table. 

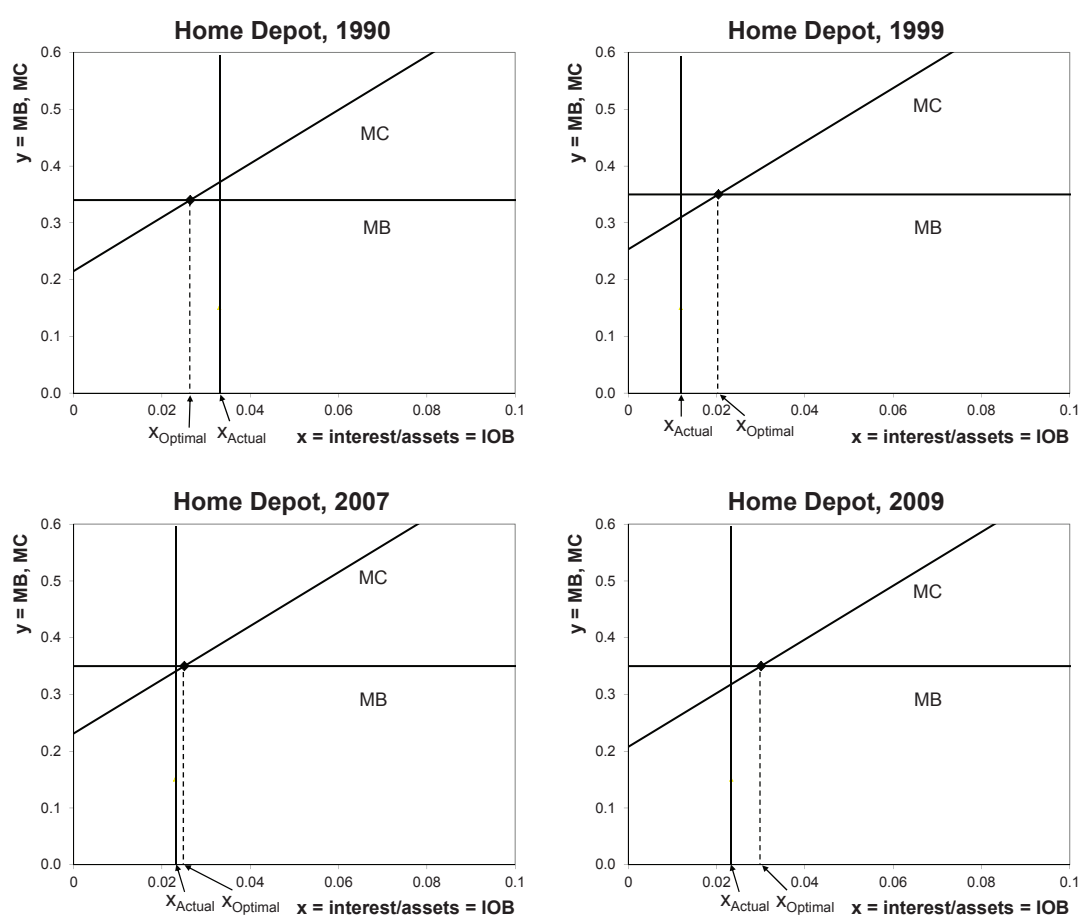

Figure 18: Marginal benefit and marginal cost curves for Home Depot in 1990, 1999, 2007, and 2009. The solid vertical line reflects the actual debt usage. The dotted vertical line reflects the optimal capital structure.

\section{Additional Cost of Debt Factors}

The optimal capital structure in previous sections is determined by equating the marginal benefit of debt to the marginal cost of debt, where the marginal cost of debt is calculated using equation (1). Equation (1) allows the cost of debt to vary in relation to six firm characteristics: the amount of collateralizable assets, firm size as measured by book assets, growth opportunities as measured by the book-to-market ratio, the amount of intangible assets, the cash flows of the firm, and whether the firm pays dividends. In this section we consider other unique company features or macro conditions that can affect the cost of debt for a given firm under various circumstances.

\subsection{Financial Divisions}

The paper so far has addressed nonfinancial companies that do not have any financial divisions. Some firms (e.g., John Deere), however, also have a finance arm, often to enhance sales by providing financing to their customers. By its very nature, a financial division typically increases a firm's overall use of debt. In addition, relative to a firm that does not have a finance division, for any given amount of debt usage, a firm with a finance arm should 

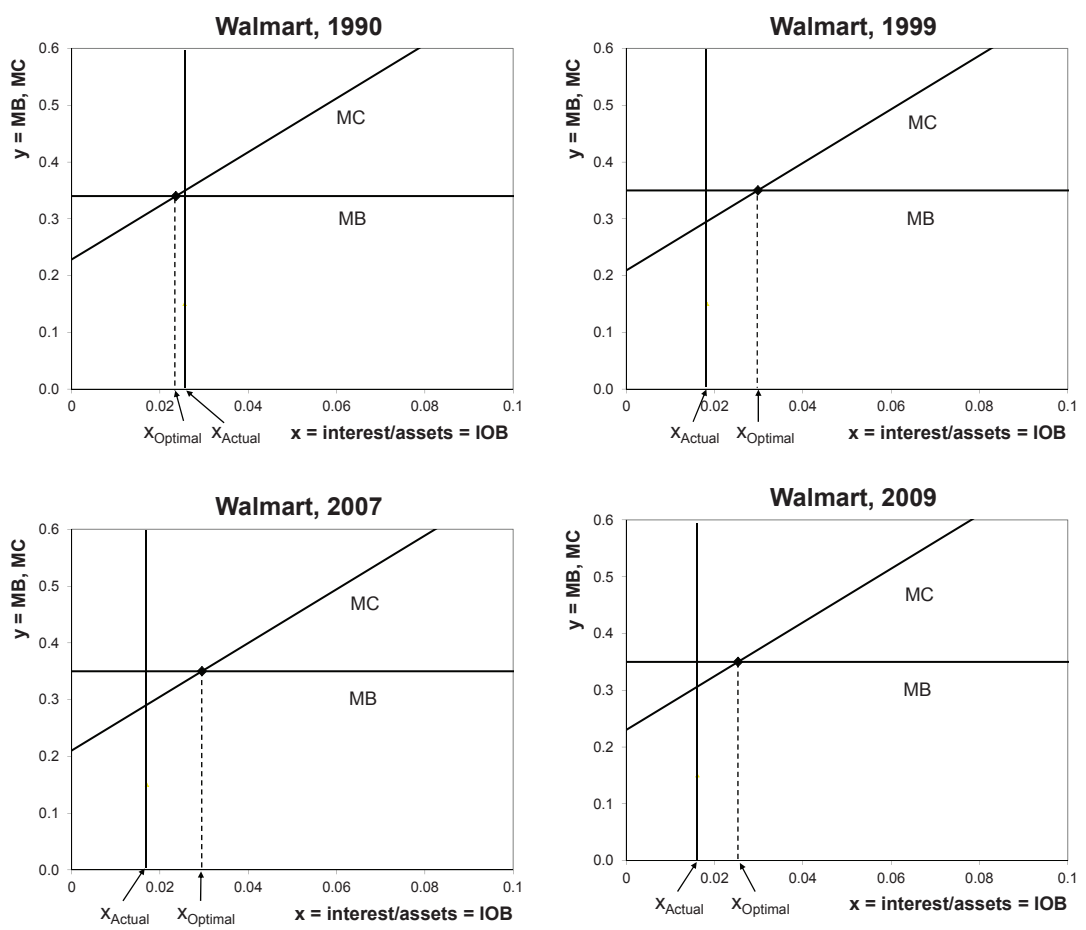

Figure 19: Marginal benefit and marginal cost curves for Walmart in 1990, 1999, 2007, and 2009. The solid vertical line reflects the actual debt usage. The dotted vertical line reflects the optimal capital structure.

have a lower cost of debt financing, all else equal. In other words, if we were to include a seventh variable in our cost of debt regression (in addition to the six firm-specific variables described above) to identify firms with finance arms, we expect the estimated coefficient associated with this seventh variable to have a negative sign.

To test this hypothesis, we include the total assets of financial divisions, relative to total book assets for the firm, as variable FTA in our specification. The mean value of FTA is 0.010. The estimated coefficient on FTA from the regression results is -0.008 , which indicates that firms with finance arms do in fact use more debt (i.e., the estimated coefficient on FTA is negative) 12 The implication is that the model predicts that firms with finance arms will have debt ratios that are about one-tenth higher than firms without finance arms, all else equal. Given this higher debt usage, the net benefits of optimal capital structure are about one-fourth greater for firms with finance arms, relative to firms without financial divisions (see panel A of Figure 20). The stakes are also higher for these finance-related firms in that the cost of deviating from the model-implied optimal capital structure is higher (see panel B of Figure 201).

\footnotetext{
${ }^{12}$ See Appendix $\mathrm{C}$ for the detailed estimation results, which are presented in column (ii) of Table 1 .
} 

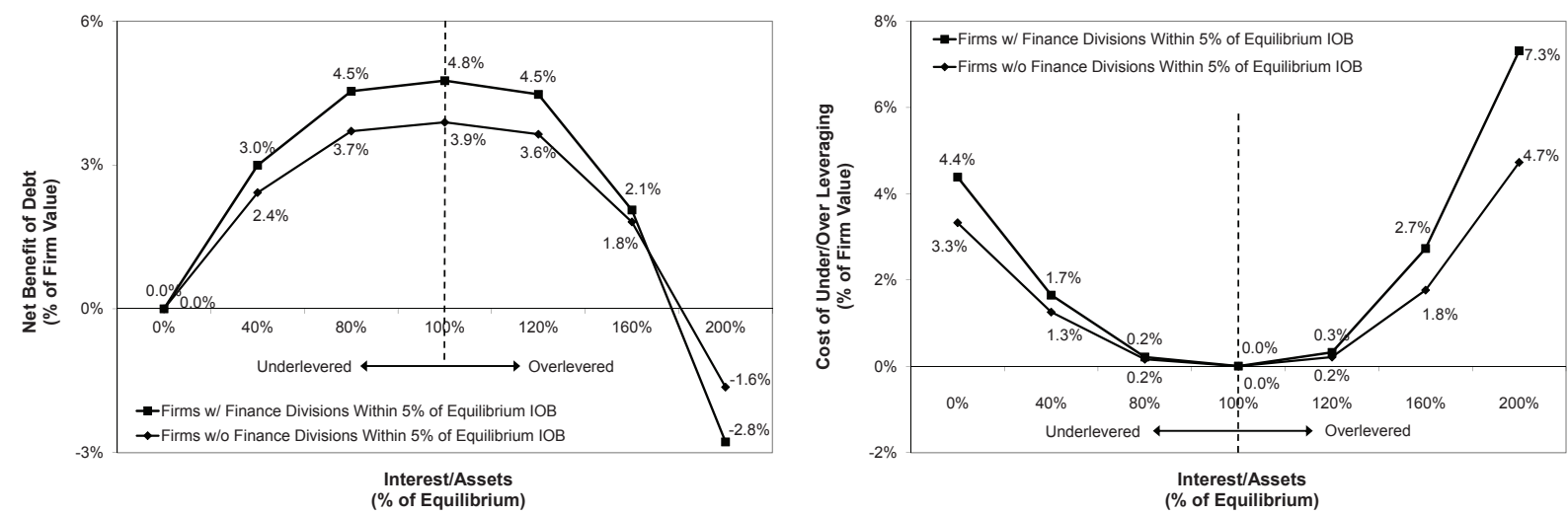

Figure 20: A) Hypothetical net benefit of debt (gross benefit minus cost of debt) for firms within $5 \%$ of their optimal IOB with financing divisions and without financing divisions. The graph shows for the typical near-equilibrium firm with financing divisions, optimal capital structure adds about $4.4 \%$ to firm value. For a firm without financing division, optimal capital structure increases firm value by about $3.7 \%$ of firm value. B) Hypothetical costs to being under or over-leveraged for the typical near-equilibrium firm with financing divisions and without financing divisions. Firms with financing divisions face higher costs to deviating from equilibrium than firms without financing divisions.

\subsection{Credit Ratings and Commercial Paper Ratings}

Recent research highlights that the supply of credit can have important effects on the amount of debt that a given firm uses (Faulkender and Petersen (2006), Leary (2009)). To capture possible supply effects, previous research has shown that firms with credit ratings use more debt than firms without. The idea is that the increased supply of available sources of debt financing is greater for firms with ratings, relative to firms without ratings. One related interpretation is that having a credit rating reduces the asymmetric information cost of using debt for the rated firm (because the rating provides helpful information to investors). This lower cost of debt translates into more debt usage.

To capture this effect, we include a variable that captures whether a company has a longterm credit rating from S\&P (LTCR) and expect to find a negative estimated regression coefficient. The regression results indicate that, as expected, having a credit rating reduces the estimated cost of debt function. The implication of the estimated coefficient is that firms with ratings will have debt ratios that are one-tenth greater than firms without ratings. Separately, we also perform this analysis identifying firms that have commercial paper ratings and find a similar effect of lower cost of debt for firms with CP ratings 13 

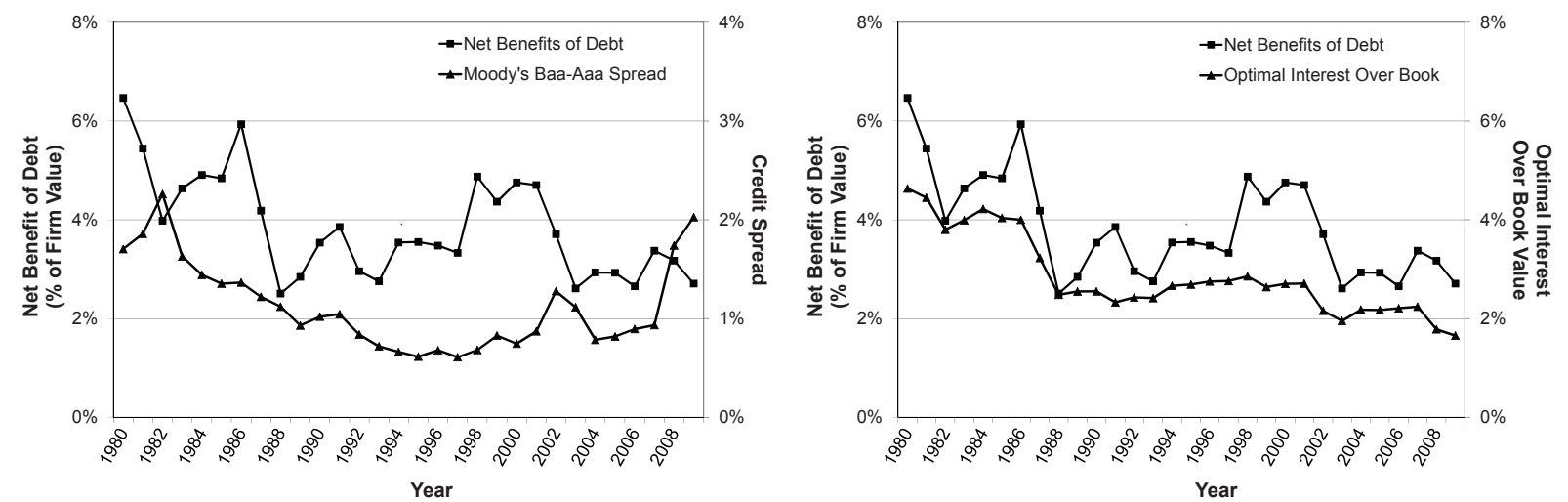

Figure 21: A) The net benefits to using debt from having an optimal capital structure against Moody's Baa-Aaa credit spread (CS) from 1980 to 2009. As the credit spread increases, the marginal cost of debt increases, reducing the net benefits from using debt. B) The net benefits to using debt from having an optimal capital structure against the optimal amount of debt usage as measured by the interest over book assets (IOB) from 1980 to 2009. Net benefits to using debt decreases with less debt usage.

\subsection{Macroeconomic Conditions and Credit Spread}

Macroeconomic conditions also influence the cost of debt. During bad economic times, we expect that the higher credit spreads will increase the cost of financing to the corporate sector, relative to times with small credit spreads. Therefore, above and beyond the influences from firm characteristics (which are captured by the variables discussed thus far), a higher credit spread should increase the cost of debt, and consequently reduce the use of debt. To account for these macroeconomic effects, we include Moody's Baa-Aaa credit spread (CS) in our estimation of the marginal cost of debt.

The estimated coefficient on the credit spread is 0.022 . This means that for years when Moody's credit spread is one standard deviation higher than the historical average, the marginal cost of debt increases for all firms by 0.022 . In other words, when the credit spread is high, the cost of debt is high. For a given marginal benefit, a higher marginal cost of debt in a bad time period (when the credit spread is high), reduces the model-recommended optimal leverage by one-seventh, leading to a reduction in net benefits by two-sevenths (see Figure 21]A for a time trend).

\footnotetext{
${ }^{13}$ See columns (iii) and (iv) of Table 1 in Appendix C.
} 


\subsection{The Enhanced Cost of Debt Specification}

The previous sections discuss additional effects that influence the cost of debt 14 This implies that there are several more variables to include in the cost of debt specification (i.e., beyond just the effects discussed in the implementation of Section 2.3). To estimate the enhanced cost of debt function, a user should proceed as in Section 2.3, but using the following enhanced information.

$$
M C(I O B)=\alpha+\beta * I O B
$$

with

$$
\begin{aligned}
\alpha= & 0.150-0.033 \text { COL }+0.026 \text { LTA }-0.023 \text { BTM }-0.020 \text { INTANG }+0.074 \text { CF }+0.053 \text { DDIV } \\
& -0.007 \text { FTA }-0.042 \text { LTCR }+0.020 \text { CS } \\
\beta= & 4.069
\end{aligned}
$$

where each of the firm characteristics, except DDIV and LTCR, is standardized (the mean is subtracted, with the result divided by the standard deviation) using the data provided in the table below. DDIV is a variable that contains a value of 1 for firms that pay dividends and a value of 0 for non-dividend paying firms. LTCR is a variable that contains a value of 1 for firms with S\&P long-term debt ratings and 0 for firms that are unrated by S\&P.

\begin{tabular}{l|ccccccc}
\hline \hline & COL & LTA & BTM & INTANG & CF & FTA & CS \\
\hline Mean & 0.493 & 5.089 & 0.766 & 0.061 & 0.094 & 0.010 & 1.094 \\
Std. Dev. & 0.231 & 2.176 & 0.631 & 0.109 & 0.149 & 0.084 & 0.443 \\
\hline \hline
\end{tabular}

COL is collateral and is the sum of physical assets and inventories divided by total book assets for a firm. LTA is the log of total book assets. BTM is the ratio of book equity to market equity. INTANG is the ratio of intangible assets to total book assets. CF is the net cashflows over total book assets. FTA is the total book values of the financing divisions as a ratio to the total book assets. CS is the credit spread between Moody's Baa rating and Moody's Aaa rating 15 Finally, IOB is interest expense over total book assets for a firm and is the measure of debt intensity.

\footnotetext{
${ }^{14}$ The final column in Table 1 of Appendix $\mathrm{C}$ presents the regression results related to including the additional variables discussed above.

${ }^{15}$ Credit spread is expressed in percentages.
} 


\section{Conclusion}

We directly simulate marginal tax benefit functions for thousands of public companies. We use variation in these benefit curves to infer a cost of debt function that is consistent with the observed capital structure choices made by firms that are neither financially distressed nor financially constrained.

The intersection of the benefit and cost curves for any given firm defines the optimal amount of debt a firm, given its characteristics. This approach indicates whether firms are correctly levered, underlevered, or overlevered. Moreover, we can determine the net benefit of using debt optimally, or the cost of using suboptimal debt. The average capitalized net benefit of debt for firms operating at the optimal capital structure is $4 \%$ of firm value and as high as $13 \%$ for some firms. The cost of using too little debt is less than the cost of using too much debt, which may explain why some firms use debt conservatively. 


\section{References}

Almedia, Heitor, and Thomas Philippon, 2007, The Risk-Adjusted Cost of Financial Distress, Journal of Finance, 62, 2557-2586.

Binsbergen, Jules H. van, Graham, John R., and Jie Yang, 2010, The Cost of Debt, Journal of Finance, 65, 2089-2136.

Faulkender, Michael, and Mitchell A. Petersen, 2006, Does the Source of Capital Affect Capital Structure?, Review of Financial Studies, 19, 45-79.

Frank, Murray Z., and Vidhan K. Goyal, 2009, Capital Structure Decisions: Which Factors are Reliably Important?, Financial Management, 38, 1-37.

Graham, John R., 2000, How Big are the Tax Benefits of Debt? Journal of Finance, 55, 1901-1941.

Graham, John R., 2001, Estimating the Tax Benefits of Debt Journal of Applied Corporate Finance, 14, 42-54.

Graham, John R., and Campbell Harvey, 2001, The Theory and Practice of Corporate Finance: Evidence from the Field Journal of Financial Economics, 60, 187-243.

Greene, W., 2008, Econometric Analysis, 6th Edition, Prentice Hall.

Leary, Mark T., 2009, Bank Loan Supply, Lender Choice, and Corporate Capital Structure, Journal of Finance, 64, 1143-1185.

Petersen, Mitchell A., 2009, Estimating standard errors in finance panel data sets: Comparing approaches, Review of Financial Studies 22, 435-480.

Thompson, Samuel B., 2009, Simple formulas for standard errors that cluster by both firm and time, Working paper, Arrowstreet Capital. 


\section{Appendix A: Details of Marginal Cost Curve Estimation}

As described in Section 2.1, we create marginal tax benefit curves of debt for a panel of approximately 132,845 firm-years between 1980 and 2009. The marginal benefit curves measure the marginal tax benefit for each dollar of incremental interest deduction.

We observe the current level of debt for each firm in each year. Henceforth, we refer to this observed level of debt as the "equilibrium amount of interest" or the "equilibrium level of debt," denoted by $x_{i, t}^{*}$. That is, we implicitly assume that for financially unconstrained, non-distressed firms, the marginal cost curve of debt $(M C)$ intersects the marginal benefit curve of debt $(M B)$ at the equilibrium level. We refer to the corresponding marginal benefit level as the "equilibrium benefit of debt," denoted by $y_{i, t}^{*}$. In equilibrium at $x_{i, t}=x_{i, t}^{*}$ the following equality holds:

$$
y_{i, t}^{*} \equiv M C_{i, t}\left(x_{i, t}^{*}\right)=M B_{i, t}\left(x_{i, t}^{*}\right) .
$$

The function $f_{i, t}$ describes the marginal benefit curve of debt for firm $i$ at time $t$ :

$$
M B_{i, t}=f_{i, t}\left(x_{i, t}\right),
$$

where $x_{i, t}$ represents the level of debt, expressed as the ratio of interest over book value of assets. Note that other measures of leverage, like the ratio of debt over the market value of assets, can alternatively be used without changing our main results.

Note that we cannot use standard ordinary least squares estimation techniques. Based on equilibrium $x_{i, t}^{*}, y_{i, t}^{*}$ choices, OLS is unable to determine whether variation is due to shifts in the cost curves or shifts in the benefit curves, and hence is unable to identify either curve correctly. Only by using instrumental variables are we able to isolate benefit shifts and therefore identify the cost curve.

To implement the instrumental variables approach, we need to identify "exogenous" shifts of the marginal benefit curve. In this context, the word exogenous indicates a shift of the marginal benefit curve that is uncorrelated with a shift in the marginal cost curve. In other words, we need to identify shocks to the marginal benefit curve of debt while holding the marginal cost curve constant. These exogenous benefit shifts may result from time series shifts of the marginal benefit curve of firm $i$, for example after a tax regime shift. Alternatively, exogenous benefit shifts may also reflect cross-sectional variation in the location of the marginal benefit curve of debt at some time $t$.

Unlike the standard framework of identifying demand and supply curves where only equilibrium points are observed, we observe the entire simulated marginal benefit curve. In other words, apart from measurement error (which we assume to be idiosyncratic), we 
directly observe the cross-sectional and time series variation (i.e., shifts) in the benefit curve, which we use to identify the cost function. Once we purge cost effects from this variation, we are left with pure shifts in benefit curves.

To implement this approach, we first compute for each firm in each year the total potential tax benefit of debt, $A R E A_{i, t}$, which is equal to the area under the marginal tax benefit curve:

$$
A R E A_{i, t}=\int_{0}^{\infty} f_{i, t}\left(x_{i, t}\right) d x_{i, t}
$$

Since the area under the curve measures the total potential tax benefits, $A R E A_{i, t}$ provides a natural description of the location of the marginal benefit curve and accommodates nonlinearities in benefits. If the marginal benefit curve shifts upward (downward), then the area under the curve increases (decreases) in tandem. Henceforth, we interpret variation in this area measure as variation (shifts) of the marginal benefit curve.

Next, we purge the benefit measure $A R E A_{i, t}$ of potential cost effects. To accomplish this, we consider a set of control variables that are theorized to be correlated with the location of the debt cost curve: a proxy for firms' collateralizable assets $\left(C O L_{i, t}\right)$, the $\log$ of total assets $\left(L T A_{i, t}\right)$, the book-to-market ratio $\left(B T M_{i, t}\right)$, a proxy for firms' intangible assets $\left(I N T A N G_{i, t}\right)$, cash flow $\left(C F_{i, t}\right)$, and whether the firm pays dividends $\left(D D I V_{i, t}\right)$. These variables are standard measures of debt costs in the literature (Frank and Goyal, 2009).

We assume that the marginal cost of debt function is linear in both interest-over-book (IOB), denoted by $x_{i, t} 16$ Under these assumptions, the marginal cost curve of debt is given by

$$
\begin{aligned}
M C_{i, t}= & a+b x_{i, t}+\theta_{C O L} C O L_{i, t}+\theta_{L T A} L T A_{i, t}+\theta_{B T M} B T M_{i, t}+\theta_{I N T A N G} I N T A N G_{i, t} \\
& +\theta_{C F} C F_{i, t}+\theta_{D D I V} D D I V_{i, t}+\xi_{i, t} .
\end{aligned}
$$

The estimated coefficient $\hat{b}$ represents the slope of the cost of debt function and the sum of $\hat{a}+\hat{\theta}_{C O L}+\hat{\theta}_{L T A}+\hat{\theta}_{B T M}+\hat{\theta}_{I N T A N G}+\hat{\theta}_{C F}+\hat{\theta}_{D D I V}$ represents the y intercept of the cost of debt function.

\footnotetext{
${ }^{16}$ Note that the linearity of the marginal cost of debt implies that the total cost of debt is a quadratic function of interest $\left(x_{i, t}\right)$. That is, if $\hat{b}$ is positive, total costs of debt increase at an increasing rate.
} 


\section{Appendix B: Details of 2SLS Estimation}

To provide statistical intuition, we discuss how two stage least squares (2SLS) could be used to estimate cost of debt functions using our primary method of identifying cost curves. First one would purge $A R E A_{i, t}$ of possible cost effects, by performing the following regression:

$$
A R E A_{i, t}=\beta_{0}+\sum_{c \in C} \beta_{c} c_{i, t}+\varepsilon_{i, t}
$$

By construction, the error term $\varepsilon_{i, t}$ of this regression is orthogonal to the regressors (i.e., the cost control variables). To the extent that the regressors span the information set that describes the location of the marginal cost curve of debt, the error term $\varepsilon_{i, t}$ can be interpreted as the exogenous variation of the marginal benefit curve of debt that is not correlated with shifts of the MC curve. This variation can be used to identify the marginal cost curve of debt. It is important to note that when purging the cost effects, we may not have controlled for all possible cost variables. As in any model specification, if this were the case this could possibly lead to omitted variable bias.

This error term, $\varepsilon_{i, t}$, which captures pure benefit shifts, is the main identifying instrument used in the 2SLS approach. The first stage of the 2SLS analysis involves projecting firms' equilibrium debt levels $x_{i, t}^{*}$ onto a constant, $\varepsilon_{i, t}$, and the control variables:

$$
\begin{aligned}
x_{i, t}^{*}= & \beta_{0}+\beta_{\varepsilon} \varepsilon_{i, t}+\beta_{C O L} C O L_{i, t}+\beta_{L T A} L T A_{i, t}+\beta_{B T M} B T M_{i, t}+\beta_{I N T A N G} I N T A N G_{i, t} \\
& +\beta_{C F} C F_{i, t}+\beta_{D D I V} D D I V_{i, t}+\eta_{i, t}
\end{aligned}
$$

where $\eta_{i, t}$ is the error term of the first-stage regression 17 In the second stage of the 2SLS approach, $y_{i, t}^{*}$ is regressed on a constant, the fitted values of the first stage regression, $\hat{x}_{i, t}^{*}$, and the control variables to obtain the slope and the intercept of the marginal cost curve.

$$
\begin{aligned}
y_{i, t}^{*}= & a+b \hat{x}_{i, t}^{*}+\delta_{C O L} C O L_{i, t}+\delta_{L T A} L T A_{i, t}+\delta_{B T M} B T M_{i, t}+\delta_{I N T A N G} I N T A N G_{i, t} \\
& +\delta_{C F} C F_{i, t}+\delta_{D D I V} D D I V_{i, t}+\xi_{i, t}
\end{aligned}
$$

where $\xi_{i, t}$ is the error term of the second-stage regression, which is uncorrelated with $\hat{x}_{i, t}$ by construction. Including the control variables in both stages of the analysis serves two purposes. First, as mentioned above, it controls for shifts in the location of the marginal cost curve. Second, it allows each control variable to affect the location of the marginal cost curve.

\footnotetext{
${ }^{17}$ Given the presence of the control variables in the first stage, $\varepsilon_{i, t}$ could be replaced in equation 8 by $A R E A_{i, t}$.
} 


\section{Appendix C: Estimation Results}

Here, we provide the estimation results of the marginal cost of debt described in the text and previous appendices in Table 1 below. Column (i) provides the results for the main marginal cost of debt function as described in equation (6):

$$
\begin{aligned}
M C_{i, t}= & a+b x_{i, t}+\theta_{C O L} C O L_{i, t}+\theta_{L T A} L T A_{i, t}+\theta_{B T M} B T M_{i, t}+\theta_{I N T A N G} I N T A N G_{i, t} \\
& +\theta_{C F} C F_{i, t}+\theta_{D D I V} D D I V_{i, t}+\xi_{i, t}
\end{aligned}
$$

where $C O L_{i, t}$ is a proxy for firms' collateralizable assets, $L T A_{i, t}$ is the $\log$ of total assets, $B T M_{i, t}$ is the book-to-market ratio, $I N T A N G_{i, t}$ is a proxy for firms' intangible assets, $C F_{i, t}$ is the cash flows, and $D D I V_{i, t}$ indicates whether the firm pays dividends.

Column (ii) provides the estimation results for the marginal cost of debt function that accounts for firms with financing divisions:

$$
\begin{aligned}
M C_{i, t}= & a+b x_{i, t}+\theta_{C O L} C O L_{i, t}+\theta_{L T A} L T A_{i, t}+\theta_{B T M} B T M_{i, t}+\theta_{I N T A N G} I N T A N G_{i, t} \\
& +\theta_{C F} C F_{i, t}+\theta_{D D I V} D D I V_{i, t}+\theta_{F T A} F T A_{i, t}+\xi_{i, t}
\end{aligned}
$$

where $F T A_{i, t}$ is the total value of the financing division as a ratio to the total book assets for firms with financing divisions and zero for firms without financing divisions.

Column (iii) provides the estimation results for the marginal cost of debt function that accounts for whether firms have a long-term debt rating:

$$
\begin{aligned}
M C_{i, t}= & a+b x_{i, t}+\theta_{C O L} C O L_{i, t}+\theta_{L T A} L T A_{i, t}+\theta_{B T M} B T M_{i, t}+\theta_{I N T A N G} I N T A N G_{i, t} \\
& +\theta_{C F} C F_{i, t}+\theta_{D D I V} D D I V_{i, t}+\theta_{L T C R} L T C R_{i, t}+\xi_{i, t}
\end{aligned}
$$

where $L T C R_{i, t}$ indicates whether the firm has a $\mathrm{S} \& \mathrm{P}$ long-term debt rating.

Column (iv) provides the estimation results for the marginal cost of debt function that accounts for whether firms have a short-term debt rating:

$$
\begin{aligned}
M C_{i, t}= & a+b x_{i, t}+\theta_{C O L} C O L_{i, t}+\theta_{L T A} L T A_{i, t}+\theta_{B T M} B T M_{i, t}+\theta_{I N T A N G} I N T A N G_{i, t} \\
& +\theta_{C F} C F_{i, t}+\theta_{D D I V} D D I V_{i, t}+\theta_{S T C R} S T C R_{i, t}+\xi_{i, t}
\end{aligned}
$$

where $S T C R_{i, t}$ indicates whether the firm has a S\&P short-term debt rating.

Column (v) provides the estimation results for the marginal cost of debt function that 
accounts for the macro environment as described by the credit spread:

$$
\begin{aligned}
M C_{i, t}= & a+b x_{i, t}+\theta_{C O L} C O L_{i, t}+\theta_{L T A} L T A_{i, t}+\theta_{B T M} B T M_{i, t}+\theta_{I N T A N G} I N T A N G_{i, t} \\
& +\theta_{C F} C F_{i, t}+\theta_{D D I V} D D I V_{i, t}+\theta_{C S} C S_{i, t}+\xi_{i, t},
\end{aligned}
$$

where $C S_{i, t}$ is the spread between Moody's Baa rating and Moody's Aaa rating.

Finally, column (vi) provides the estimation results for the marginal cost of debt function that includes all relevant cost variables above:

$$
\begin{aligned}
M C_{i, t}= & a+b x_{i, t}+\theta_{C O L} C O L_{i, t}+\theta_{L T A} L T A_{i, t}+\theta_{B T M} B T M_{i, t}+\theta_{I N T A N G} I N T A N G_{i, t} \\
& +\theta_{C F} C F_{i, t}+\theta_{D D I V} D D I V_{i, t}+\theta_{F T A} F T A_{i, t}+\theta_{L T C R} L T C R_{i, t}+\theta_{C S} C S_{i, t}+\xi_{i, t} .
\end{aligned}
$$


Table 1:

This table provides coefficient estimates for the marginal cost of debt using IV analysis, where $M C_{i, t}=$ $a+b x_{i, t}+\sum_{c \in C} \theta_{c} c_{i, t}+\xi_{i, t} . \quad x_{i, t}$ is the observed interest expenses over book value $(I O B)$ and the instrumental variable used is the area under the marginal benefit curve $(A R E A)$. $C$ is the set of cost control variables. Column (i) estimates over $C \equiv\{C O L, L T A, B T M, I N T A N G, C F, D D I V\}$, the main set of control variables. Column (ii) estimates over $C$ and FTA. Column (iii) estimates over $C$ and LTCR. Column (iv) estimates over $C$ and $S T C R$. Column (v) estimates over $C$ and $C S$. Column (vi) estimates over $C, F T A, L T C R$, and $C S$. $C O L$ is a proxy for firms' collateralizable assets over total book assets, $L T A$ is the log of total assets, $B T M$ is the book-to-market ratio, INTANG is a proxy for firms' intangible assets over total book assets, $C F$ is the cash flows over total book assets, and $D D I V$ indicates whether the firm pays dividends. FTA is the value of the financing division over total book assets, $L T C R$ indicates whether the firm has a S\&P long-term debt rating, $S T C R$ indicates whether the firm has a S\&P short-term debt rating, and $C S$ is the spread between Moody's Baa rating and Moody's Aaa rating. All control variables, except $D D I V, L T C R$, and $S T C R$ are standardized to have mean zero and standard deviation one based on all firms. $D D I V, L T C R$, and $S T C R$ are binary variables with values $\{0,1\}$. Robust, clustered standard errors are reported in parentheses. Standard errors are clustered by both firm and year as in Thompson (2009) and Petersen (2009). Significance at the $10 \%$ level is indicated by $*, 5 \%$ level by $* *$, and $1 \%$ level by $* * *$.

\begin{tabular}{|c|c|c|c|c|c|c|}
\hline & (i) & (ii) & (iii) & (iv) & (v) & (vi) \\
\hline Constant & $\begin{array}{l}0.117 \text { *** } \\
(0.018)\end{array}$ & $\begin{array}{l}0.116^{* * *} \\
(0.018)\end{array}$ & $\begin{array}{l}0.125 * * * \\
(0.017)\end{array}$ & $\begin{array}{l}0.118 \text { *** } \\
(0.017)\end{array}$ & $\begin{array}{l}0.147 \text { *** } \\
(0.017)\end{array}$ & $\begin{array}{l}0.150 * * * \\
(0.017)\end{array}$ \\
\hline $\mathrm{IOB}$ & $\begin{array}{l}4.733 \text { *** } \\
(0.534)\end{array}$ & $\begin{array}{l}4.743 * * * \\
(0.534)\end{array}$ & $\begin{array}{l}4.743 \text { *** } \\
(0.514)\end{array}$ & $\begin{array}{l}4.723 \text { *** } \\
(0.525)\end{array}$ & $\begin{array}{l}3.985 \\
(0.435)\end{array}$ & $\begin{array}{l}4.069 \text { *** } \\
(0.436)\end{array}$ \\
\hline $\mathrm{COL}$ & $\begin{array}{l}-0.039 * * * \\
(0.005)\end{array}$ & $\begin{array}{l}-0.039 * * * \\
(0.005)\end{array}$ & $\begin{array}{l}-0.038 * * * \\
(0.005)\end{array}$ & $\begin{array}{l}-0.039 * * * \\
(0.005)\end{array}$ & $\begin{array}{l}-0.034 * * * \\
(0.004)\end{array}$ & $\begin{array}{l}-0.033 * * * \\
(0.004)\end{array}$ \\
\hline LTA & $\begin{array}{l}0.015 * * * \\
(0.003)\end{array}$ & $\begin{array}{l}0.015 * * * \\
(0.003)\end{array}$ & $\begin{array}{l}0.029 * * * \\
(0.003)\end{array}$ & $\begin{array}{l}0.020 * * * \\
(0.003)\end{array}$ & $\begin{array}{l}0.016 \text { *** } \\
(0.003)\end{array}$ & $\begin{array}{l}0.026 \text { *** } \\
(0.003)\end{array}$ \\
\hline BTM & $\begin{array}{l}-0.018 * * * \\
(0.004)\end{array}$ & $\begin{array}{l}-0.018 * * * \\
(0.004)\end{array}$ & $\begin{array}{l}-0.020 * * * \\
(0.004)\end{array}$ & $\begin{array}{l}-0.019 * * * \\
(0.004)\end{array}$ & $\begin{array}{l}-0.022 * * * \\
(0.004)\end{array}$ & $\begin{array}{l}-0.023 * * * \\
(0.004)\end{array}$ \\
\hline INTANG & $\begin{array}{l}-0.024 * * * \\
(0.004)\end{array}$ & $\begin{array}{l}-0.024 * * * \\
(0.004)\end{array}$ & $\begin{array}{l}-0.022 * * * \\
(0.004)\end{array}$ & $\begin{array}{l}-0.024 * * * \\
(0.004)\end{array}$ & $\begin{array}{l}-0.021 * * * \\
(0.003)\end{array}$ & $\begin{array}{l}-0.020 * * * \\
(0.004)\end{array}$ \\
\hline $\mathrm{CF}$ & $\begin{array}{l}0.080 * * * \\
(0.007)\end{array}$ & $\begin{array}{l}0.080 * * * \\
(0.007)\end{array}$ & $\begin{array}{l}0.078 * * * \\
(0.007)\end{array}$ & $\begin{array}{l}0.080 * * * \\
(0.007)\end{array}$ & $\begin{array}{l}0.075 * * * \\
(0.006)\end{array}$ & $\begin{array}{l}0.074 \text { *** } \\
(0.006)\end{array}$ \\
\hline DDIV & $\begin{array}{l}0.063 * * * \\
(0.007)\end{array}$ & $\begin{array}{l}0.064 \text { *** } \\
(0.007)\end{array}$ & $\begin{array}{l}0.062 \text { *** } \\
(0.007)\end{array}$ & $\begin{array}{l}0.065 * * * \\
(0.007)\end{array}$ & $\begin{array}{l}0.053 * * * \\
(0.006)\end{array}$ & $\begin{array}{l}0.053 \text { *** } \\
(0.006)\end{array}$ \\
\hline FTA & & $\begin{array}{l}-0.008 * \\
(0.004)\end{array}$ & & & & $\begin{array}{l}-0.007 * \\
(0.004)\end{array}$ \\
\hline LTCR & & & $\begin{array}{l}-0.054 * * * \\
(0.008)\end{array}$ & & & $\begin{array}{l}-0.042^{* * *} \\
(0.007)\end{array}$ \\
\hline STCR & & & & $\begin{array}{l}-0.035 * * * \\
(0.008)\end{array}$ & & \\
\hline CS & & & & & $\begin{array}{l}0.022 \text { *** } \\
(0.005)\end{array}$ & $\begin{array}{l}0.020 * * * \\
(0.005)\end{array}$ \\
\hline No. Obs. & 13,519 & 13,519 & 13,519 & 13,519 & 13,519 & 13,519 \\
\hline
\end{tabular}

